\title{
The Potential of Permanent Gullies in Europe as Geomorphosites
}

\author{
Wojciech Zgłobicki $^{1}$ (D) Jean Poesen ${ }^{2} \cdot$ Marianne Cohen $^{3} \cdot$ Maurizio Del Monte $^{4}$ • \\ José M. Garć́a-Ruiz ${ }^{5}$ Ion Ionita ${ }^{6} \cdot$ Lilian Niacsu $^{6} \cdot$ Zora Machová $^{7}$. \\ José F. Martín-Duque $^{8} \cdot$ Estela Nadal-Romero $^{9} \cdot$ Alessia Pica $^{4} \cdot$ Freddy Rey $^{10}$. \\ Albert Solé-Benet ${ }^{11} \cdot$ Miloš Stankoviansky ${ }^{7}$. Christian Stolz ${ }^{12,13} \cdot$ Dino Torri $^{14}$. \\ Juris Soms ${ }^{15}$ - Francesca Vergari ${ }^{4}$
}

Received: 12 December 2016/Accepted: 18 July 2017 /Published online: 29 July 2017

(C) The Author(s) 2017. This article is an open access publication

\begin{abstract}
Geotourism is a useful way to educate societies in the field of geomorphology and related natural hazards. Geosites, including geomorphosites, represent the basis for the development of this type of tourism. This study describes 12 representative gully regions within nine European
\end{abstract}

Wojciech Zgłobicki

wojciech.zglobicki@umcs.pl

Jean Poesen

jean.poesen@kuleuven.be

Marianne Cohen

marianne.cohen@paris-sorbonne.fr

Maurizio Del Monte

maurizio.delmonte@uniroma1.it

José M. García-Ruiz

humberto@ipe.csic.es

Ion Ionita

ion.ionita72@yahoo.com

Lilian Niacsu

lilianniacsu@yahoo.com

Zora Machová

zora.machova@uniba.sk

José F. Martín-Duque

josefco@geo.ucm.es

Estela Nadal-Romero

estelanr@unizar.es

Alessia Pica

alessia.pica@uniroma1.it

Freddy Rey

freddy.rey@irstea.fr

Albert Solé-Benet

albert@eeza.csic.es countries. The characteristics of 42 permanent gullies, gully systems, and badland landscapes are presented. Based on scientific values of the sites, educational lessons to be learned were identified that are mainly related to (i) gullies as a geological window, (ii) present-day geomorphological processes

Miloš Stankoviansky

stankoviansky.milos@gmail.com

Christian Stolz

Christian.Stolz@uni-flensburg.de

Dino Torri

dibiti2001@gmail.com

Juris Soms

juris.soms@du.lv

Francesca Vergari

francesca.vergari@uniroma1.it

1 Faculty of Earth Sciences and Spatial Management, Maria Curie-Sklodowska University, Kraśnicka 2cd, 20-718 Lublin, Poland

2 Division of Geography and Tourism, KU Leuven, Celestijnenlaan 200E, 3001 Leuven, Belgium

3 UMR ENeC, University Paris-Sorbonne, 191 rue Saint Jacques, 75005 Paris, France

4 Department of Earth Sciences, Sapienza University of Rome, Piazzale Aldo Moro 5, 00185 Rome, Italy

5 Instituto Pirenaico de Ecología, Consejo Superior de Investigaciones Científicas (IPE-CSIC), Campus de Aula Dei, P.O. Box 13034, 50080 Zaragoza, Spain

6 Faculty of Geography and Geology, Alexandru Ioan Cuza University of Iasi, Carol I Blvd., No. 20A, 700505 Iasi, Romania

7 Department of Physical Geography and Geoecology, Faculty of Natural Sciences, Comenius University in Bratislava, Mlynská dolina, Ilkovičova 6, 84215 Bratislava 4, Slovakia 
and (iii) stages of historical gully erosion reflecting past human-environment interactions. To evaluate possible education activities, a geotouristic assessment of the studied gullies and badlands was made, based on scientific, educational, functional and touristic indicators. This assessment demonstrates a large difference between the selected gully and badland sites, particularly with regard to functional and tourist values. The geotouristic potential of gullies (badlands) is the highest in Italy and Spain and the lowest in Romania and Latvia. In some countries, permanent gullies are not regarded as geotouristic attractions at all, while in others, they constitute a significant element of their tourism development strategy. In our opinion, all activities must be part of a broader strategy for the development of geotourism in gully and badland regions, for example, gullies may be included as geosites within existing or planned geoparks.

\section{Keywords Gullies · Badlands · Geoheritage $\cdot$ Geotourism}

\section{Introduction}

Educating society about processes shaping the surface of the Earth is a fundamental task and a challenge of contemporary geomorphology. Scientific progress about understanding the origin, age and dynamics of landforms has been impressive. However, geomorphologists should make a greater effort to demonstrate the relevance of their discipline to a wider audience and not to be an "invisible scientific discipline" (Tooth 2009; Giusti 2012). Raising the public awareness of natural hazards is fairly important (e.g. Dunbar 2007; Coratza and De Waele 2012). Contemporary geomorphological processes may cause negative impacts for people and society, and it is

8 Department of Geodynamics and Geosciences Institute (CSIC, UCM), Complutense University, 28040 Madrid, Spain

9 Department of Geography, Environmental Sciences Institute (IUCA), University of Zaragoza, Pedro Cerbuna 12, 50009 Zaragoza, Spain

10 Irstea, UR EMGR, Université Grenoble Alpes, 2 rue de la Papeterie, BP 76, 38402 Saint-Martin-d'Hères, France

11 Estación Experimental de Zonas Aridas, Consejo Superior de Investigaciones Cientificas (EEZA-CSIC), Carretera de Sacramento s/n, La Cañada de San Urbano, 04120 Almeria, Spain

12 Department of Geography, Europe-University, Auf dem Campus 1, 25943 Flensburg, Germany

13 Geographical Institute, Johannes Gutenberg University, 55099 Mainz, Germany

14 National Research Council, Research Institute for Hydrogeological Protection, Via Madonna Alta 126, 06128 Perugia, Italy

15 Department of Geography, Faculty of Natural Sciences and Mathematics, Daugavpils University, Parādes 1, Daugavpils LV-5401, Latvia much easier to efficiently counteract these phenomena when the general public understands the nature and scale of the threat. This study focusses on one of these processes, namely gully erosion, which is a major natural hazard in many parts of the world (Valentin et al. 2005; Castillo and Gomez 2016). One of its consequences is the formation of permanent channels, which leads to an increased valley density. Land management becomes difficult in highly dissected terrains. The impact of permanent gullies on historical and present-day land use and agriculture can be observed at both local and regional scales (e.g. Kuhlman et al. 2010; Zgłobicki and BaranZgłobicka 2011; Vergari et al. 2013; Yitbarek et al. 2012; Zgłobicki et al. 2015a).

Applying the concept of geotourism, geoparks, and geosites (including geomorphosites) to particular landforms is the best way to transfer geomorphological knowledge to society (e.g. Thomas 2012; Hose 2013; Zgłobicki et al. 2015b). A geosite is a geosphere feature of particular significance for understanding the history of the Earth (Reynard 2004). Geosites should have a protective, scientific, educational and touristic function. Geomorphosites are landforms of high scientific value that should also be attractive for tourists, i.e. sites having cultural, ecological and aesthetic values (Panizza 2001). According to Reynard (2005), "a geomorphosite is a landform to which a value can be attributed." This means that a geomorphosite cannot exist if it does not have one or more significant values from the human perspective (Pereira and Pereira 2010). Apart from being important for scientific knowledge about the Earth, climate and life history (representing a basic value), geomorphosites should also attract tourists (e.g. Reynard et al. 2011; Zgłobicki and Baran-Zgłobicka 2013). Different types of sites can be distinguished (e.g. Giusti et al. 2013): (i) landforms (e.g. tors, sinkholes, waterfalls at knickpoints in river channels), (ii) rock and sediment outcrops providing insights into the origin of the land surface (visible in, e.g. road cuts, quarries and gravel pits) and (iii) viewpoints offering an opportunity to examine landform diversity at a larger scale (mountain ridges, escarpments). The classification of geomorphosites is mainly based on their origin (Ielenicz 2009). The designation and management of sites are inevitably associated with a range of practical issues. These include the selection of sites to be presented, their representativeness, the level and quality of information offered, provision of adequate access and avoidance of potential conflicts with interest of nature conservation, among others.

So far, 131 research papers indexed in the Web of Science (all databases, at 01.05.2017) contain the term "geomorphosite or geomorphosites" in their titles. These papers deal with (i) terminology and methodology problems (Panizza 2001; Reynard and Coratza 2007; Reynard 2008; Erhartic 2010; Kubaliková 2013), (ii) synthetic reviews of geomorphosites at national scale (Giusti and Calvet 2010; Warowna et al. 2013; Kale 2014) and (iii) specific types of geomorphosites such as glacial (Garavaglia and Pelfini 2011), fluvial (Wiederkehr et al. 2010), anthropogenic 
(Del Monte et al. 2013) and granitic (Ginesu and Secchi 2009). In addition, several special journal issues related to geomorphosites have been published as well, i.e. Reynard and Coratza (2007), Giusti (2010) and Reynard et al. (2016a).

Permanent gullies are channels, cut into unconsolidated rocks and regolith, typically by ephemeral flow from rainstorms or meltwater. Such channels are relatively narrow and deep (up to 25-30 m) and difficult to cross, to ascend or, in cropland, to erase by conventional tillage equipment (Poesen et al. 2003; Goudie 2004; Neboit 2010; Vanmaercke et al. 2016). Badlands are deeply and densely dissected erosional landscapes (with many permanent gullies), formed in soft rock terrain, commonly but not exclusively in semi-arid regions (Torri et al. 2000; Goudie 2004).

Permanent gullies and badlands in Europe have been described regionally and as case studies. De Ploey (1989) produced a map of West Europe indicating badland areas, i.e. areas having high gully densities (see also Poesen and Hooke 1997; Nadal-Romero et al. 2011). However, there are no systematic overviews of the most important regions and sites with permanent gullies at the subcontinental scale. The number of publications dealing with gullies as geomorphosites is also very small. Some studies indicate that permanent gullies in the upland regions of Poland are tourist attractions (Zgłobicki and Baran-Zgłobicka 2013). The geotouristic value of loess geoheritage, including gullies (Warowna et al. 2016) and the educational possibilities (Zgłobicki et al. 2015b), were also assessed. Gullies were also included in regional studies on geotourism (e.g. Gregori et al. 2005; Solarska and Jary 2010; Coratza et al. 2011; Vujičić et al. 2011; Papčo 2014; Bollati et al. 2016).

In the era of digital media, web-accessible open databases of geosites play the most important role in the development of geotourism. They offer the first insight into the geodiversity of an area, help plan geotouristic routes and act as virtual guides. They should contain information about the scientific value of the site itself, as well as practical tips on getting there and around (Zgłobicki et al. 2015b). Such databases are developed in some European countries, for example in Spain, Italy or Poland.

Therefore, the objectives of this study are (i) to select representative gully regions/sites (case-study areas) in various European regions, (ii) to indicate the most important scientific and educational lessons to be learned from these sites and (iii) to evaluate the geotouristic value of the selected gully sites.

\section{Materials and Methods}

\section{Permanent Gullies in Europe}

Based on a literature review, 12 major gully regions located in 9 European countries were identified (Fig. 1). The studied countries were selected to represent the most contrasting European regions (in terms of physical geography) with gullies, i.e. North, Central and South Europe. The most important climatological and lithological regions where gully erosion is a typical geomorphic process were included in the study. Table 1 provides more information on some characteristics of these regions. Gullies and badlands from these regions have been described in several publications. The selected individual gullies and badland zones must be seen as examples to illustrate the value of gullies for education and tourism rather than being representative of each country or of Europe as a whole.

Two main types of gully regions can be distinguished. Firstly, there are badlands that developed on slightly consolidated formations in south Europe under Mediterranean climatic conditions, and these may have a natural or anthropogenic origin. Secondly, permanent gullies formed in loose sediments, in Western and Central Europe, most often in loess deposits, and their development are strongly linked to past and current agricultural activity under temperate to continental climate. The spatial scale and complexity of these forms are different. Single gullies represent geotope scale, while badlands are gully-rich scenery or group of gullies forming a network (a geosystem scale).

The diversity of natural environmental characteristics, geology, climate and topography, within and between the gully regions, is thus considerable (for characteristics of gully regions, see Table 1), enabling the selection and study of diverse gully sites. Within each gully region, one or more gully sites have been selected as representative geomorphosites. In the following list, a brief description of gullies from the selected countries is given.

A) Italy. Permanent gullies are often grouped in severely eroded areas, sometimes forming badlands, where they show spectacular erosion forms. Gully erosion is pervasive in several climatic, geomorphological and lithological situations. It can attain interesting and intriguing landforms in fine-textured lithologies such as calanco amphitheaters (Fig. 2b) and biancana fields (Fig. 2a; Vittorini 1977; Alexander 1980; Torri et al. 1994; Calzolari and Ungaro 1998).

B) Spain. The development of gullies is one of the most important and widespread geomorphic processes in Spain because of erosive rains, steep topography, low vegetation cover, land use changes and high erodibility of some bedrocks (mainly marls), particularly in the eastern sector of the Iberian Peninsula (Fig. 2c-e; Poesen and Hooke 1997; García Ruiz and López Bermúdez 2009; García-Ruiz et al. 2013). Quaternary neotectonic activity, aridity since the beginning of the Holocene and recurrent fires have had significant effects on the origin of many gullies (Cerdà 1998; Maher and Harvey 2008). There are 
Fig. 1 Location of the studied gully regions in Europe (source of contour map: http://d-maps.com/ carte.php?num_car=2233\&lang= en). 1 Ombrone and Tiber River Basins, 2 Inner Depression, Central Pyrenees, 3 Ebro Depression,4 Central Spain, 5 Tabernas desert, 6 Digne Prealps, 7 Falciu Hills, 8 Myjava Hill Land, 9 Taunus Mts., Aar river valley, 10 Nałęczów Plateau, Lublin Upland,11 Brabant Loam Region, 12 Lower Gauja spillway valley

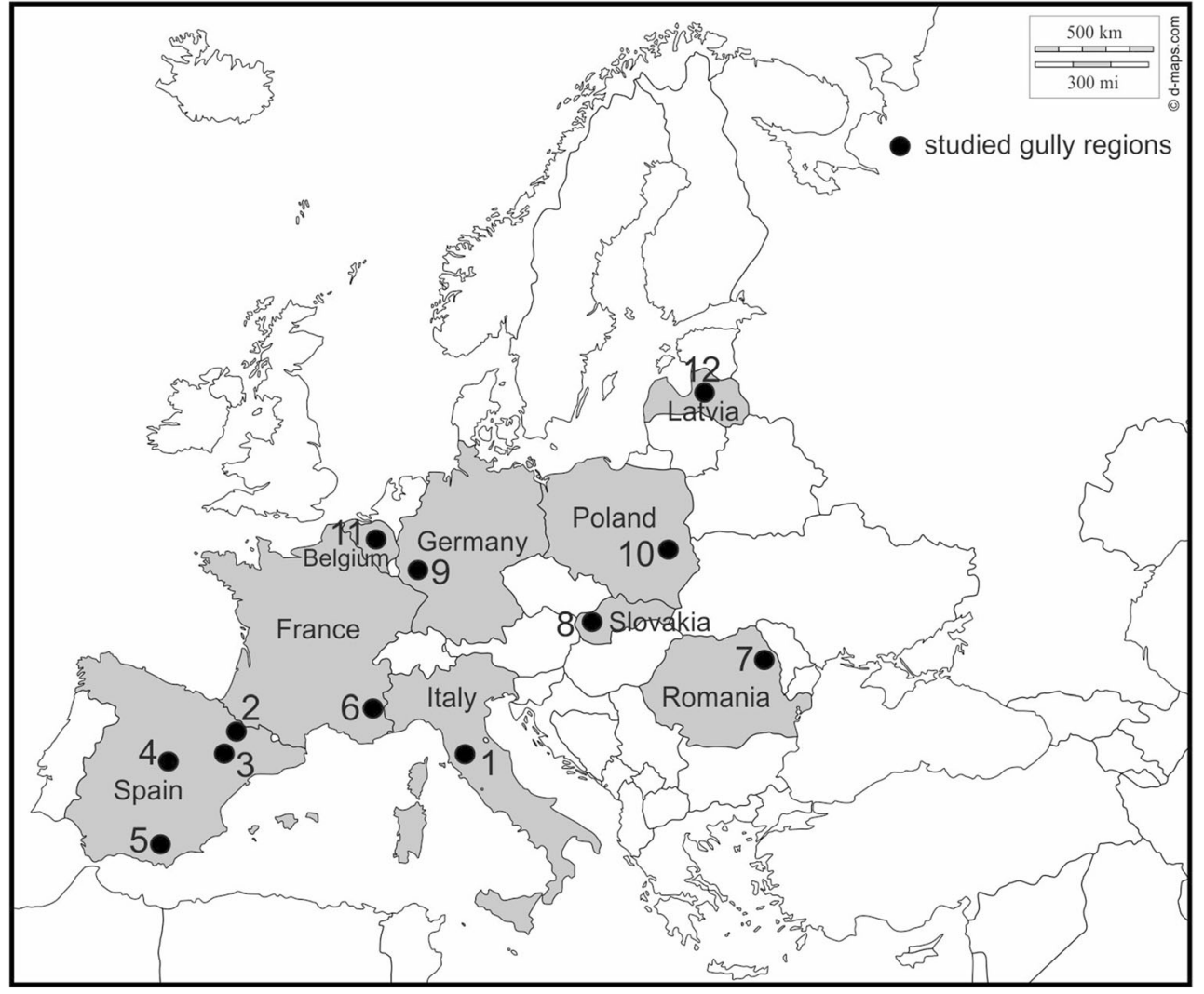

also evidences that intense quarrying activities during the last centuries have triggered gullying processes in Central Spain (Ballesteros Cánovas et al. 2017).

C) France. Gullies in East France are mainly permanent ones (Mathys et al. 2003, 2005; Yamakoshi et al. 2009), and most of them developed due to intense soil erosion in the nineteenth century as a consequence of deforestation and overgrazing (Vallauri et al. 2002). Gullies in France are mainly present on marly terrains in the French Southern Alps, especially in the Digne Prealps and the Baronnies (Fig. 2f), but they are also present on fluvioglacial alluvial deposits or on moraines in diverse mountainous lands (Ballais 1996; Lecompte et al. 1998).

D) Romania. The main gully regions in Romania are located in the Moldavian Plateau, Getic Plateau and subCarpathians, especially on deforested hilly areas covered by loess-like deposits, sandy and sandy-clayey layers (Fig. 2g). The Moldavian Plateau of eastern Romania is the most representative area where gullies are welldeveloped and the average density may exceed $3 \mathrm{~km} \mathrm{~km}^{-2}$ (Radoane et al. 1995). All over Romania, the main causes of gully erosion are human activities in areas having high natural risk to gullying.

E) Germany. Human-induced soil erosion by water first occurred in the Neolithic and rose during the Iron Age, High Middle Ages, up to Modern Times (Dotterweich 2008;
Bork et al. 1998). This resulted in the formation of gullies and badlands which can be observed in several German regions. Especially, locations in the German uplands (Rhenish Slate Mts., South German Scarplands, Hessian and Lower Saxonian Uplands) have been affected by gully erosion (Fig. 2h) (Bork et al. 1998; Stolz and Grunert 2006; Stolz 2008; for a review, see Dotterweich 2008). Figure $3 \mathrm{~b}$ illustrates the spatial patterns of gully density in the Aar valley (West Germany).

F) Slovakia. Extensive areas were affected by gully erosion in the past resulting in the formation of relatively dense network of permanent gullies, exceeding locally $3 \mathrm{~km} \mathrm{~km}^{-2}$; see the map by Bučko and Mazúrová (1958) (Figs. 2 i and 4). Field observations, however, revealed here and there significantly higher gully densities reaching in some places $11 \mathrm{~km} \mathrm{~km}^{-2}$ (Midriak 1966; Stankoviansky 2003a). The most dense gully network is found in uplands and hills (Fig. 4), where two major factors control concentrated flow erosion rates, i.e. favourable geological conditions (a deep regolith) and land use (mostly pastures and arable land).

G) Poland. Total length of the permanent gullies is ca. $40,000 \mathrm{~km}$ and the areas characterized by gully densities $>0.5 \mathrm{~km} \mathrm{~km}^{-2}$ cover almost $20,000 \mathrm{~km}^{2}$ (Józefaciuk and Józefaciuk 1996). The highest density of permanent gullies occurs in the southern part of the country: in the 


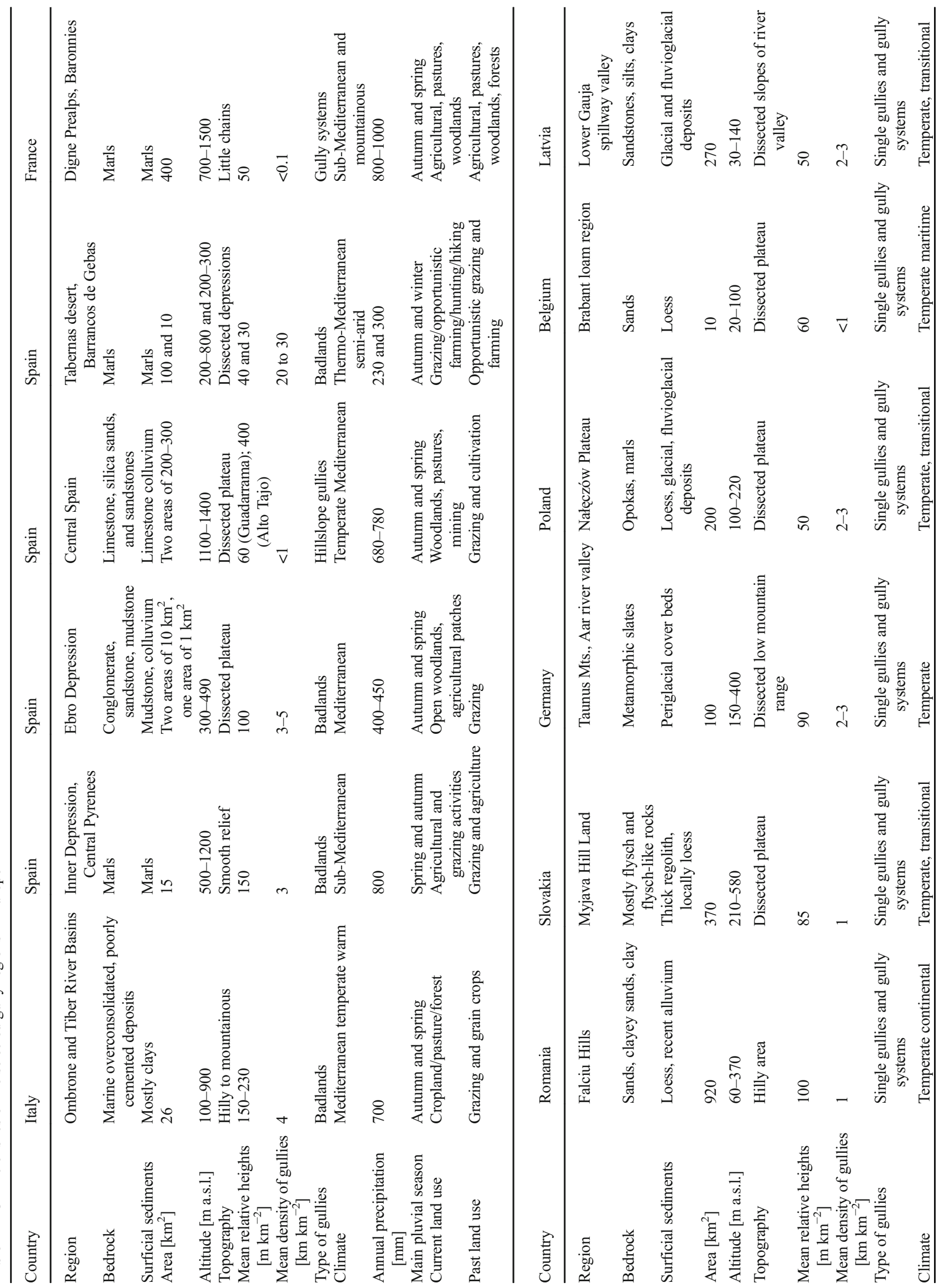


Beskidy Mts., Carpathian Foreland and within the loess uplands. In some upland areas, gully density may exceed $20 \mathrm{~km} \mathrm{~km}^{-2}$ (Gawrysiak and Harasimiuk 2012) which results from the high erodibility of loess, steep topography, high density of rural roads and low cover by forests, meadows and pastures (Figs. $2 \mathrm{j}$ and 3a) (Dotterweich et al. 2012).

H) Belgium. Ephemeral gullies are common in loamy to sandy loam croplands with rolling topography. However, by definition, these ephemeral gullies never become permanent. Therefore, there are few permanent gullies in Central Belgium. These are typically found in the loess belt under luvisols. Two types of permanent gullies can be observed: (1) permanent gullies in old forests (i.e. forested since at least the second half of the eighteenth century) of the loess belt (Fig. 2k) and (2) road gullies (sunken lanes) which are mainly found in cropland areas (Vanwalleghem et al. 2003, 2005).

I) Latvia. Analysis of the spatial distribution of permanent gullies allows to distinguish several regions, where these landforms are common, i.e. (1) the territories of glacial uplands, particularly in areas where the landscape is dominated by plateau-like hills or large-sized morainic hummocks, (2) the territories along river valleys and proglacial spillways and (3) the territories along tunnel valleys in uplands. In these territories, linear erosion landforms are widespread features in the landscape, and in some places, they constitute a very dense channel network, whereas in lowland areas, permanent gullies occur occasionally and are generally not commosn (Fig. 21; Soms 2011).

\section{Geotouristic Assessment}

The selection of countries, regions and sites with gullies was made on the basis of a literature review and field studies. The main criterion was to have one or more representative gully sites for the most important gully regions in Europe. Selected regions are characterized by various natural conditions (i.e. geology, soils, geomorphology and climate), land use and touristic activities.

Next, a protocol to collect the most important information about these gully regions (scientific and touristic values) was designed (Table 2). Going further, a database of potential geomorphosites (gullies) was accomplished and a questionnaire for nine lessons to be learned from each selected gully site was made. The most important educational issues were identified by means of data provided in the questionnaire.

An assessment based on several indicators and subindicators to evaluate the geotouristic values of the selected gullies as geomorphosites was prepared. This assessment was based on the common indicators used in similar studies 
Fig. 2 Illustration of selected gully sites in representative gully regions of Europe. a Orcia Valley, Southern Tuscany, Italy (photo: M. Del Monte). b Calanchi Valley, Northern Latium, Italy (photo: M. Del Monte). c Cárcava del Pez, Segovia, Spain (photo: J.F. Martín Duque). d Central Pyrenees, Spain (photo: E. NadalRomero). e Tabernas desert, Spain (photo: A. Sole Benet). f Saignon Catchment, La Mottedu-Caire, Digne Prealps, France (photo: Freddy Rey). g PuriceniBahnari, Romania (photo: I. Ionita). h Aar Valley, Germany (photo: Ch. Stolz). i Babikovce, Slovakia (photo: P. Papčo). j Doły Podmularskie, Lublin Upland, Poland (photo: W. Zgłobicki). k Meerdaal Forest, Central Belgium (photo: J. Poesen). I Lielā

Kautraka grava, Vidzeme Upland, Latvia (photo: J. Soms)
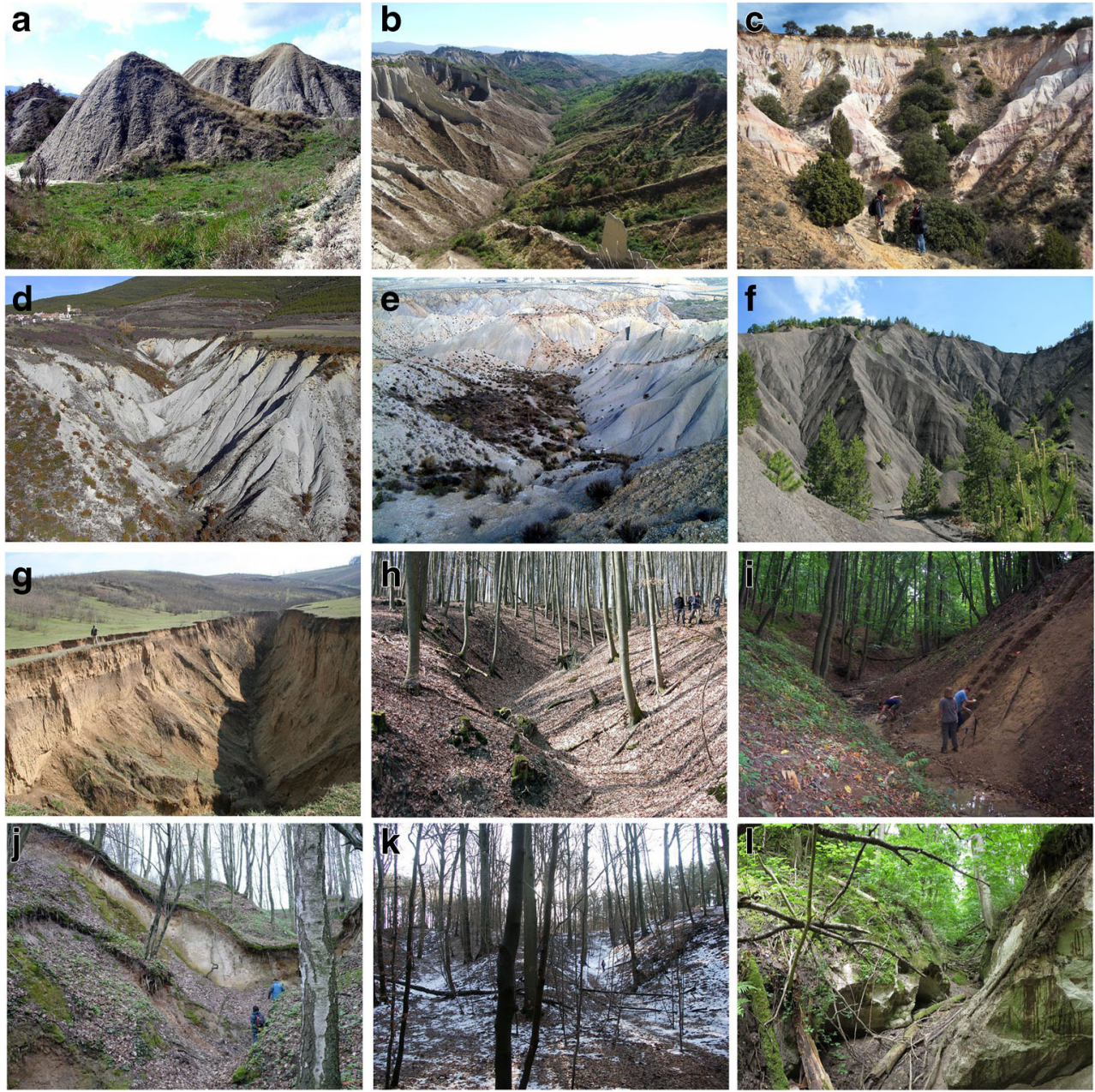

(see, e.g. Reynard et al. 2007, 2016b; Vujičić et al. 2011; Kubalikova 2013; Neches 2013; Kubalikova and Kirchner 2016; Warowna et al. 2016). These indicators were divided into two groups: (i) main values (scientific and educational) and (ii) additional values (functional and touristic). It was assumed that the scientific and educational values of the gully sites are the key features to establish a geomorphosite, but the role of additional values is also important. In total, 24 subindicators were used (Table 2).

One should keep in mind that the evaluation is, to a certain extent, biased by the fact that each gully site was evaluated by a different team of researchers. This could be improved in the future, but it remains quite difficult to travel around with all authors to visit all gully sites for evaluation. However, to reduce the bias, we used as many objective (quantitative) subindicators as possible.

For the data analysis, we also used the geosite assessment model (GAM) proposed by Vujičić et al. (2011). GAM is a graph (matrix) that consists of nine fields (zones) into which geosites can be classified according to the scores they received in the assessment. The $X$-axis represents the main values (scientific and educational) while the $Y$-axis indicates additional values (touristic and functional). Major gridlines that create fields have values of 3 units on the $X$-axis and 5 units for the $Y$ axis. This model indicates what type of action should be taken (which type of values should be improved) to increase the suitability of gully sites for tourism.

\section{Results}

\section{Permanent Gullies in Studied Regions}

The proposed Italian sites were selected as possible geomorphosites because (i) they are representative of the severely gullied (badlands) landscapes characterizing the Central Italy Pliocene marine deposits; (ii) they are the result of particular interrelations between geomorphic processes and human (economic) activity, culture and history; and (iii) they have been the subject of many scientific investigations and, thus, provide many opportunities for scientific dissemination of geomorphological hazards and human-induced landscape 

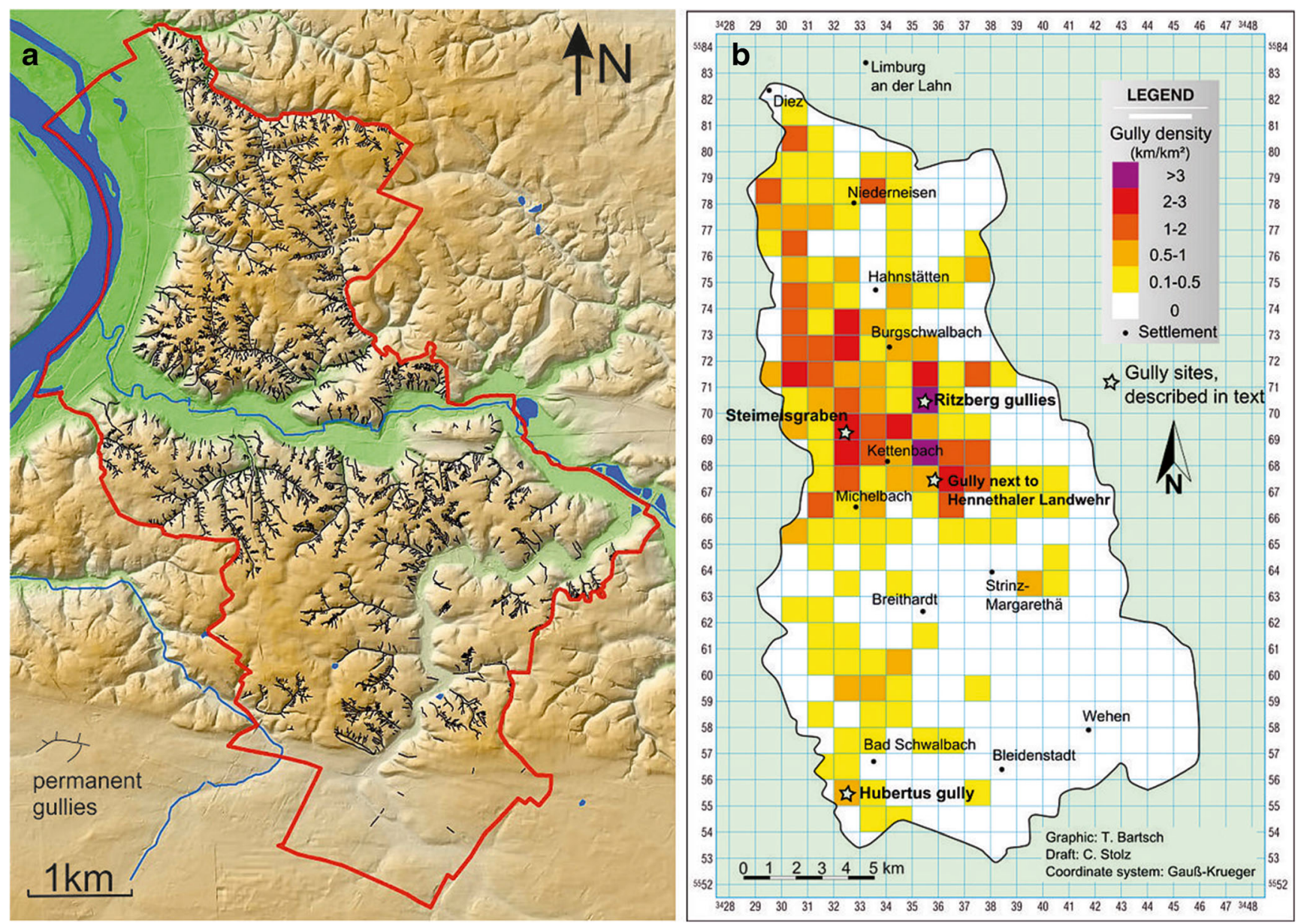

Fig. 3 Illustration of permanent gully densities under forests in Central and West Europe. a Gully pattern in the Kazimierz Dolny district, East Poland (DEM by L. Gawrysiak). b Aar Valley, south-west Germany

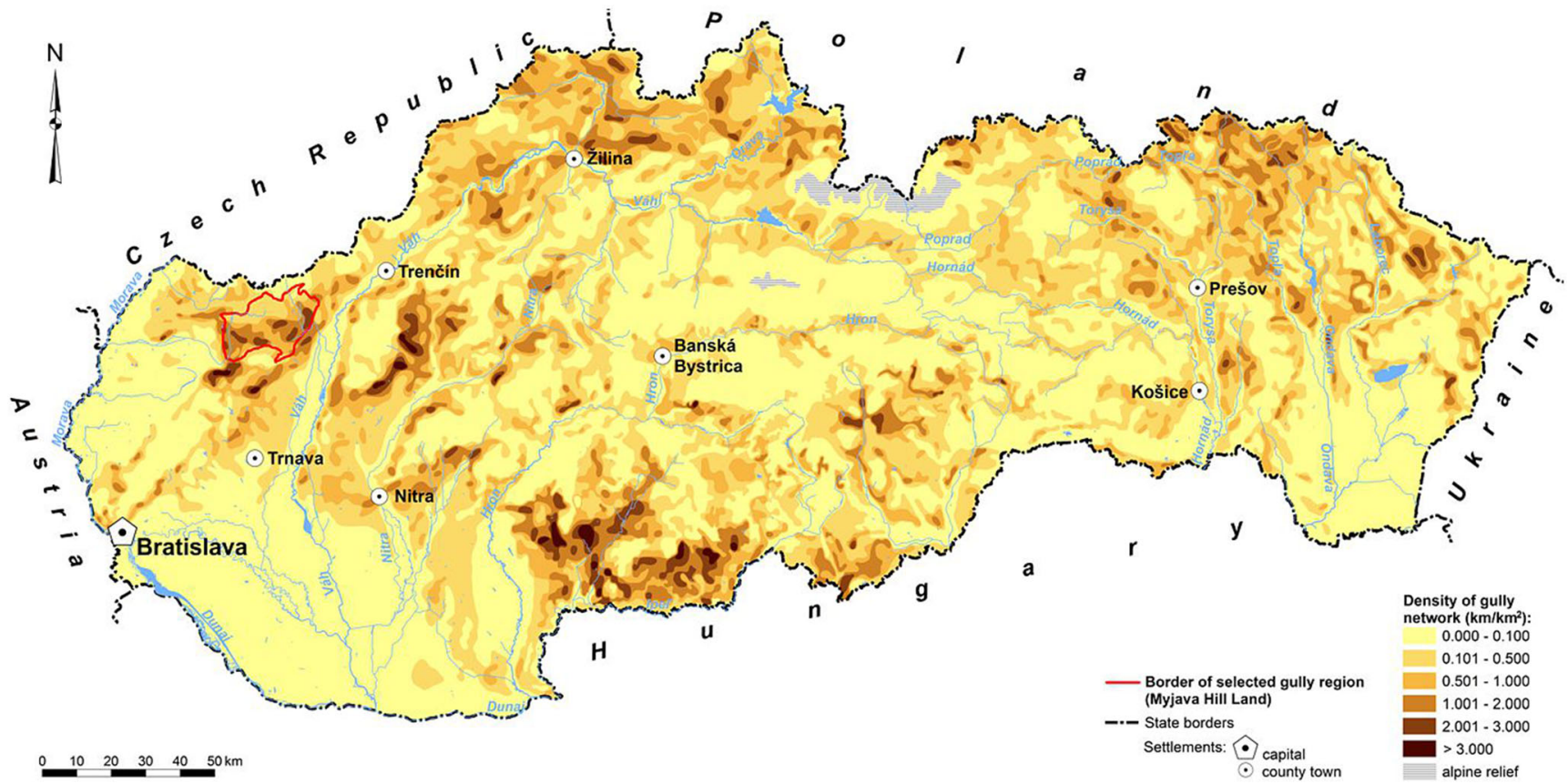

Fig. 4 Map of gully network density in Slovakia (elaborated by Štefan Koco, based on the 1:400,000 map by Bučko and Mazúrová 1958) with location of studied gully region 
Table 2 Indicators, subindicators and scores for the geotouristic assessment of gully sites as potential geomorphosites (after Warowna et al. 2014, modified)

Indicators and subindicators $\quad$ Scores

A. Scientific and educational value

A1. Scientific knowledge

A2. Rarity

A3. Geodiversity

A4. Degree of degradation

A5. Clarity of features

A6. Exposure (visibility)

A7. Educational content

A8. Available educational or promotional products (leaflets, maps, booklets)

A9. Legal protection status

B. Functional value

B1. Location against road network

B2. Accessibility (getting there)

B3. Direct access (difficulty of reaching the site)

B4. Tourism infrastructure (parking lots, resting places, toilets)

B5. Food and lodging services

B6. Fragility (risks)

B7. Form of ownership

C. Tourist value

C1. Biotic value of the site

C2. Aesthetic value of the site

C3. Viewpoints in the vicinity

C4. Surrounding landscape (absence of human-induced deterioration)
0.0 - unknown, no scientific publications

0.5 - only local scientific publications

1.0 - several scientific publications, including international publications

0.0 - not among the top three most important geosites in the region

0.5 - one of the three most important geosites in the region

1.0 - the only geosite in the region

0.0 - only one abiotic feature (process) [i.e. geologic, pedologic, geomorphic, or hydrologic]

$0.5--2$ visible abiotic features

$1.0-3$ or more abiotic features

0.0 - highly degraded

0.5 - slightly degraded (significant geomorphological/geological features are preserved)

1.0 - lack of visible degradation (well-conserved)

0.0 - low

0.5 -medium (primarily for experts)

1.0 - high (also for non-experts)

0.0 - obstacles to observation all year round (e.g. vegetation)

0.5 - obstacles to observation during some seasons only

1.0 - no obstacles to observation

0.0 - the site clearly exemplifies features for the educational levels of college and university cycles

0.5 - the site clearly exemplifies features for all levels of the educational system

1.0 - the site clearly exemplifies features for all levels of education. The site is also suitable for explaining processes of environmental change among social groups or sectors not specifically integrated into the educational system

0.0 - none

$0.5-1$ or 2 types of products

$1.0-3$ and more types of products

0.0 - none

0.5 -landscape park, Natura 2000

1.0 - protected site (national park, nature reserve, site of natural interest)

0.0 - no direct access by paved road

0.5 - local road at a distance less than $10 \mathrm{~km}$ and the major road at a distance $>25 \mathrm{~km}$

1.0 - major road at a distance less than $25 \mathrm{~km}$

0.0 - by car and more than $1000 \mathrm{~m}$ walking distance

0.5 - by car and less than $500 \mathrm{~m}$ walking distance

1.0 - by public transport and less than $500 \mathrm{~m}$ walking distance

0.0 - difficult access (vegetation, type of substratum)

0.5 - minor obstacles to access or accessibility during some season(s) of the year

1.0 - no obstacles to access

0.0 - none

0.5 - at a distance more than $1 \mathrm{~km}$

1.0 - at a distance less than $1 \mathrm{~km}$

0.0 - no food and lodging services for groups of 30 people $<15 \mathrm{~km}$

0.5 - food and lodging services for groups of 30 people at $<15 \mathrm{~km}$

1.0 - food and lodging services for groups of 30 people at $<5 \mathrm{~km}$

0.0 - highly fragile by public use

0.5 - some deterioration possible

1.0 - difficult to deteriorate

0.0 - private

0.5 - public (restrictions of use, e.g. nature reserve)

1.0 - public (no restrictions of use)

0.0 - no biotic value

0.5 - some biotic value

1.0 -rich biotic value

0.0 - site not present in the iconography of the region

0.5 - typical aesthetical value for the region

1.0 - emblematic site (landmark) of the region

0.0 - no viewpoints in the vicinity $(3-4 \mathrm{~km})$

0.5 -viewpoint 1-2 km away

1.0 -viewpoint up to $1 \mathrm{~km}$ away (or the site is the viewpoint)

0.0 - considerable human-induced deterioration

0.5 - natural/human-transformed landscape 
Table 2 (continued)

\begin{tabular}{ll}
\hline Indicators and subindicators & Scores \\
\hline & $1.0-$ natural landscape without disturbing anthropogenic elements \\
C5. Presence of tourist trails and educational paths at & $0.0-$ path or trail more than $3 \mathrm{~km}$ away \\
the site & $0.5-$ path or trail up to $3 \mathrm{~km}$ away \\
& $1.0-$ the site lies on a trail or path \\
C6. Location in relation to major tourist centres & $0.0-$ more than $15 \mathrm{~km}$ away \\
& $0.5-5$ to $15 \mathrm{~km}$ away \\
& $1.0-$ up to $5 \mathrm{~km}$ away \\
C7. Additional sites of interest (within 30 min walking & $0.0-$ none \\
distance or up to $5 \mathrm{~km}$ by car) & $0.5-$ biotic and anthropogenic (cultural sites) \\
& $1.0-$ abiotic, biotic, and cultural sites, geosites in close proximity \\
C8. Potential demand & $0.0-<50,000$ inhabitants within a distance of $50 \mathrm{~km}$ \\
& $0.5->50,000-100,000$ inhabitants within a distance of $50 \mathrm{~km}$ \\
& $1.0->100,000$ inhabitants within a distance of $50 \mathrm{~km}$ \\
\hline
\end{tabular}

transformation (e.g. Aucelli et al. 2014; Del Monte et al. 2014; Neugirg et al. 2016; Torri et al. 2013; Vergari 2015).

The biancana badlands are characterized by a cascade of irregular domes/rounded cones/hummocks, with a basal diameter typically ranging between 2 and $8 \mathrm{~m}$, and protruding 3 to $7 \mathrm{~m}$ above the surrounding soil surface (Fig. 2b) where gully erosion interacts with pseudo-karst processes such as pipes and sinkholes. The calanco badlands (Fig. 2a) are composed of an extremely dissected, rapidly developing landscape, characterized by rill and gully landforms and a very dense dendritic drainage network (Vittorini 1977; Alexander 1980). Calanco badlands comprise very deep gullies and rills accompanied by mass movements, especially along the gully banks and gully heads.

Four main areas have been selected that have some of the most spectacular gully landscapes in Spain (Figs. 1 and 2c-e): (1) gullies in a marly, humid and cold environment in the Inner Depression of the Central Pyrenees, resulting in the development of very active badlands (Nadal-Romero et al. 2008; Nadal-Romero and Regüés 2010); (2) gullies and associated landforms in the Ebro Depression, a semi-arid environment composed of large mudstone outcrops alternating with sandstone layers (Desir and Marín 2007; Sancho et al. 2008); (3) gullies on silica sand bedrock in central Spain located in a semi-arid to subhumid environment with a high diversity of landforms (Lucía et al. 2011; Martín-Moreno et al. 2014); and (4) gullies in Southeast Spain, which may be the most wellknown gully and badland region of Europe (Braga et al. 2003; Calvo-Cases et al. 2014). All gully sites selected in Spain represent distinct geomorphic processes in a variety of climatic and geologic environments, resulting in a large variability of landforms and erosion and sediment transport processes. The presence of the most active and large gully areas is related to lithology and to historical and recent land use changes going back to the Bronze Age in some cases (Constante et al. 2010; García-Ruiz 2010), while others (SE Spain) are due to the combination of tectonic activity and aridity since the beginning of the Holocene.
Permanent gullies in France are mainly studied in the Southern Alps, on Callovo-Oxfordian marly terrains, and in a mountainous Mediterranean climate (Fig. 2e). The selected gully sites appear in the Digne Prealps (Draix site) and in the Baronnies. They represent the most spectacular landforms in the country. Four sites, with gully systems all on marly terrains, have been selected. Several issues may be present in the gullies: (i) badlands consisting of typical actively eroding gullies, (ii) restored gullies with vegetation installed on gully slopes and floors together with bioengineering structures and (iii) erosion control programmes began 140 years ago which allow the evaluation of their effectiveness after a long period (Mathys et al. 2003; Cohen and Rey 2005; Rey 2009). Scientific values are well-documented because of the several research projects that were conducted here.

Land degradation due to gully erosion has been recognized as a major environmental threat in the southern part of the Moldavian Plateau (east Romania), particularly in the Falciu Hills (Fig. 2g). Four continuous valley-bottom gullies have been selected for their scientific and scenic values. The scientific value is associated to their very high mean gully head retreat rate $\left(14 \mathrm{~m}\right.$ year $\left.^{-1}\right)$ over the last two centuries and the significant sediment yield by gullying representing 54-69\% of total soil loss due to water erosion (Ionita 2006; Ionita et al. 2015). The gullied catchments of the Falciu Hills represent some of the most spectacular case scenarios of human impact on gully erosion in Europe.

As an example for a typical gully region, the Aar valley (Taunus Mts., Rhenish Massif) was selected (Stolz and Grunert 2006; Stolz 2008). The gullies in the Aar area are concentrated around a former iron work. The density reaches up to $3 \mathrm{~km} \mathrm{~km}^{-2}$ (Fig. 3; Stolz 2008). Today, most gullies are located under forests and are cut in thick periglacial cover beds of loess-like sediments and local metamorphic rocks and, furthermore, in strongly weathered argillaceous schists. During the seventeenth century and even before, forests in this area have been largely cut. Some of the gully systems form badlands, others are typical dendritic branched. 
Gully sites in Slovakia, in the Myjava Hill Land gully region (Figs. $2 \mathrm{i}$ and 4 ) were selected based on their scientific value, i.e. specific linkage of gullies to historical artificial linear landscape elements (Bradlo, Kostolné, Vad'ovce), the high gully density (Vad'ovce, Kostolné), information on dates of gully formation using historical-religious sources (Prietrž Church), identification of gully stages (Babikovce) and significant contemporary remodelling of historical gullies due to extreme rainfall events in 2009 (Kunov).

The five gullies selected as geosites in Poland are characterized by unique and above-average geoheritage values (Fig. $2 \mathrm{j}$ ). All are easily accessible and located close to each other, which makes it possible to visit them in 1 day. Located within a landscape park and a planned geopark, the selected gullies are listed in Poland's Central Register of Geosites. These gullies are also characterized by various scientific (fossil gully from Bronze Age, active gullying, geological profiles, outstanding sunken lane) and touristic values (Zgłobicki et al. 2015b).

For this study, we selected the old permanent gullies in Meerdaal Forest and those in Neigem Forest in central Belgium for several reasons. Both old forests have very well-preserved old gully systems that formed centuries ago under a different land use type (i.e. cropland or overgrazed land). Such permanent gullies are relatively rare in the loess belt of Belgium because of the limited area covered by forest. Both forests are open to the public. The characteristics and genesis of these gullies have been discussed in research papers (e.g. Vanwalleghem et al. 2003, 2005; Schotmans et al. 2015). Gullies in the Meerdaal Forest have been selected because they are, to our knowledge, the only gullies known in Europe dating from the Roman period (Fig. 2k; Vanwalleghem et al. 2006).

Conditions for gully erosion network development in Lower Gauja spillway valley (Latvia) are very favourable due to lithological and geomorphological factors (Fig. 21). During incision and deepening of gully channels, cutting through the impermeable strata of clayey or loamy glacial till strata and exposing the water table of unconfined aquifers associated with permeable water-bearing Devonian sandstones resulted in seepage, drainage of groundwater and formation of springs producing permanent runoff in gully channels. This caused extensive branching of gullies and the development of many headcuts and landslide-cirque gullies on the banks of permanent gullies. In many gullies and their branches, Devonian rock outcrops can be observed (Soms 2011).

\section{Lessons to Be Learned}

Scientific and educational lessons to be learned from the 42 gully sites can be divided into three groups (Table 3 ). The first group comprises lessons that are the main scientific messages in $50 \%$ or more of the selected gullies, i.e. (i) active geomorphic processes (62\% of sites), (ii) phases of gully erosion in historical times $(61 \%)$ and (iii) valuable outcrops of bedrock or sedimentary deposits (52\%). The second group comprises lessons related to (i) gully erosion as a natural hazard (29\%) and (ii) human impact on present-day gully erosion (26\%). The third group consists of lessons that can only be learned as very important message in a limited number of gully sites, i.e. reclamation of degraded sites/areas by gully erosion (10\%), gullies as important sites for biodiversity (9\%), mitigation of gully erosion (8\%) and present-day degradation of geoheritage in gullies (2\%). It should be noticed that, for example, almost all sites are important sites from the point of view of biodiversity.

There is also a spatial variation of lessons to be learned from the studied gully sites in Europe:

a) Valuable outcrops of bedrock or sedimentary layers within gully channels: Spain, Italy, selected sites in France, Slovakia, Poland and Latvia

b) Active geomorphic processes (i.e. gully headcut and sidewall retreat, piping, gully wall failure): Spain, Italy, France and Romania

c) Phases of gully erosion in historical times: Germany, Slovakia, Belgium, Latvia, selected sites in Spain and Italy

d) Human impact (land use changes) on present-day gully erosion: Spain, Italy and Romania

e) Gully erosion as a natural hazard: Romania, Italy and France

f) Mitigation of gully erosion: France and Slovakia

g) Reclamation of degraded sites/areas by gully erosion or mining on gullied landscapes: Spain and Italy

h) Present-day degradation of geoheritage in gullies: Poland and France

i) Gullies as important sites for biodiversity: France

The individual regions and countries also differ with regard to lessons to be learned from the gully sites. The largest number of lessons is reported for Spain, France and some sites in Italy, and a smaller number in Belgium, Poland, Germany, Romania, Slovakia and Latvia. It is related to the spatial scale and diversity of the sites. Badlands (geosystem scale) offer more lessons while gullies and gully systems (geofacies scale) are sites with one to three important and interesting scientific messages to the geotourists (Table 3).

\section{Gullies as Geosites at Country Level}

Each country shows different levels of progress in the inventory of geosites and attention to geoheritage. National inventories exist in most countries except for Belgium, Romania and Latvia (Table 4). In France, this inventory is still on 
progress. Gullies in Spain, Italy and Poland are recognized as geosites. Information on the geotouristic values of gullies from Spain and Poland have been published in international or national journals, whereas little or no information is available in Romania and Belgium.

The touristic values of the gully regions under study also show a large variation. In Italy and Poland, these regions have a high touristic value, a developed infrastructure and a high intensity of tourist traffic (Table 5), even if the reason attracting people is incommensurably more the cultural than the geo part of the attraction, at least in Italy. In contrast, Romania's Falciu Hills region with spectacular gullies lacks touristic infrastructure and is rarely visited by tourists (Fig. $2 \mathrm{~g}$ ). The other gully regions usually have high natural and cultural values, quite well-developed tourism infrastructure and a moderate to high intensity of tourist traffic.

\section{Geotourist Potential of Gullies}

The geotouristic assessment of the selected gullies as potential geomorphosites yielded various results. The maximum total score for individual gully sites in Italy and Spain was $85 \%$ of the maximum score (i.e. 24), while in the case of Slovakia and Poland, sometimes it reaches only about $50 \%$. The mean total score for all gully sites at the country level also varied: from $81 \%$ for Italy to $62 \%$ for Slovakia (Fig. 5).

The total score for the scientific and educational values of the selected gullies as geomorphosites was quite high with a mean value of $72 \%$ of the maximum possible score (i.e. 9). The corresponding scores for Italy, Spain and Romania exceed $80 \%$, whereas gullies in Slovakia, Latvia and Poland received the lowest scores. The total score for the functional values was slightly lower, i.e. a mean value of $70 \%$ of the maximum score value (i.e. 7). Gullies in Germany and Slovakia received the highest scores for these values, while those for Spain and Poland ranked the lowest. The selected gullies received the lowest scores for their touristic values (60\% of the maximum possible score, i.e. 8 ), with Italy and Belgium at the top (about 70\%) and France and Romania (having just over 50\%) at the bottom of the country list (Fig. 6).

Analyses of matrix (GAM) indicated that over $75 \%$ of the gullies were highly rated with regard to the main values (scientific and educational) or additional values (functional and tourist). Twelve gullies (representing about $20 \%$ of the total) were highly rated in both general groups of indicators. There are four sites from Italy; two from Belgium, Spain, and Poland; and one gully from Germany and Slovakia. Nine gullies received medium scores in both general groups (Fig. 7). Twenty-nine gullies belong to the category "high value" of main values; for additional value, only 15 sites are so highly rated.

There is a positive correlation $\left(r^{2}=0.72\right.$ and 0.77$)$ between total geotouristic value and scientific-educational value $\left(r^{2}=0.72\right)$ and touristic value $\left(r^{2}=0.77\right)$. No correlations were found between three main groups of values (scientific, functional and touristic).

Out of 24 geotouristic subindicators assessed, the highest mean score ( $90 \%$ of the maximum value) was given for subindicators in the scientific and educational value groups, i.e. scientific knowledge, geodiversity, degree of degradation and clarity of features (Table 2). The lowest score ( $40 \%$ of the maximum value) was given to other subindicators from the same group, i.e. available educational or promotional products (leaflets, maps, booklets) and legal protection status. Some functional and touristic subindicators received poor rating ( $50 \%$ of the maximum value), i.e. accessibility (getting there), aesthetic value of the site, and presence of other sites of interest (within 30 min walking distance or up to $5 \mathrm{~km}$ by car). No relation was found between scientific and educational values on the one hand and functional or touristic values on the other hand.

\section{Discussion}

\section{Scientific and Educational Lessons to Be Learned from Gully Sites}

Many gully sites allow one to learn more about the geomorphic processes that shaped them, the geology of the region through the rock types that outcropped in gully walls, the land use during which the gullies formed and developed, the natural hazard they represent, the land cover that caused or controlled the gullies and finally the effective mitigation and reclamation of these erosion features or conditions that lead to their destruction or infilling (Fig. 8). In this section, a summary of the main scientific and educational lessons that can be learned from gully geomorphosites in the selected European countries is given.

\section{A. Active Geomorphic Processes}

Badlands in Spain, Italy and France, located in totally or partially bare landscapes, represent natural laboratories for the study of hydrological and soil erosion processes, i.e. from weathering of the parent material (e.g. mudstones, marls, granite), particle detachment by rain drops, transport by runoff, mass wasting processes, piping erosion and sediment deposition in local colluvial fans as well (Nadal-Romero et al. 2007; Nadal-Romero and Regüés 2010). Gully channel networks from badlands nicely illustrate how landscapes become dissected and how a drainage network develops. In contrast, permanent gullies in Central and West Europe are typically in a dormant stage. In Poland, however, geomorphological processes such as piping, mass movements and headcut erosion can be reactivated by particular land use changes within gully catchments (Fig. 8b; Rodzik et al. 2009). 


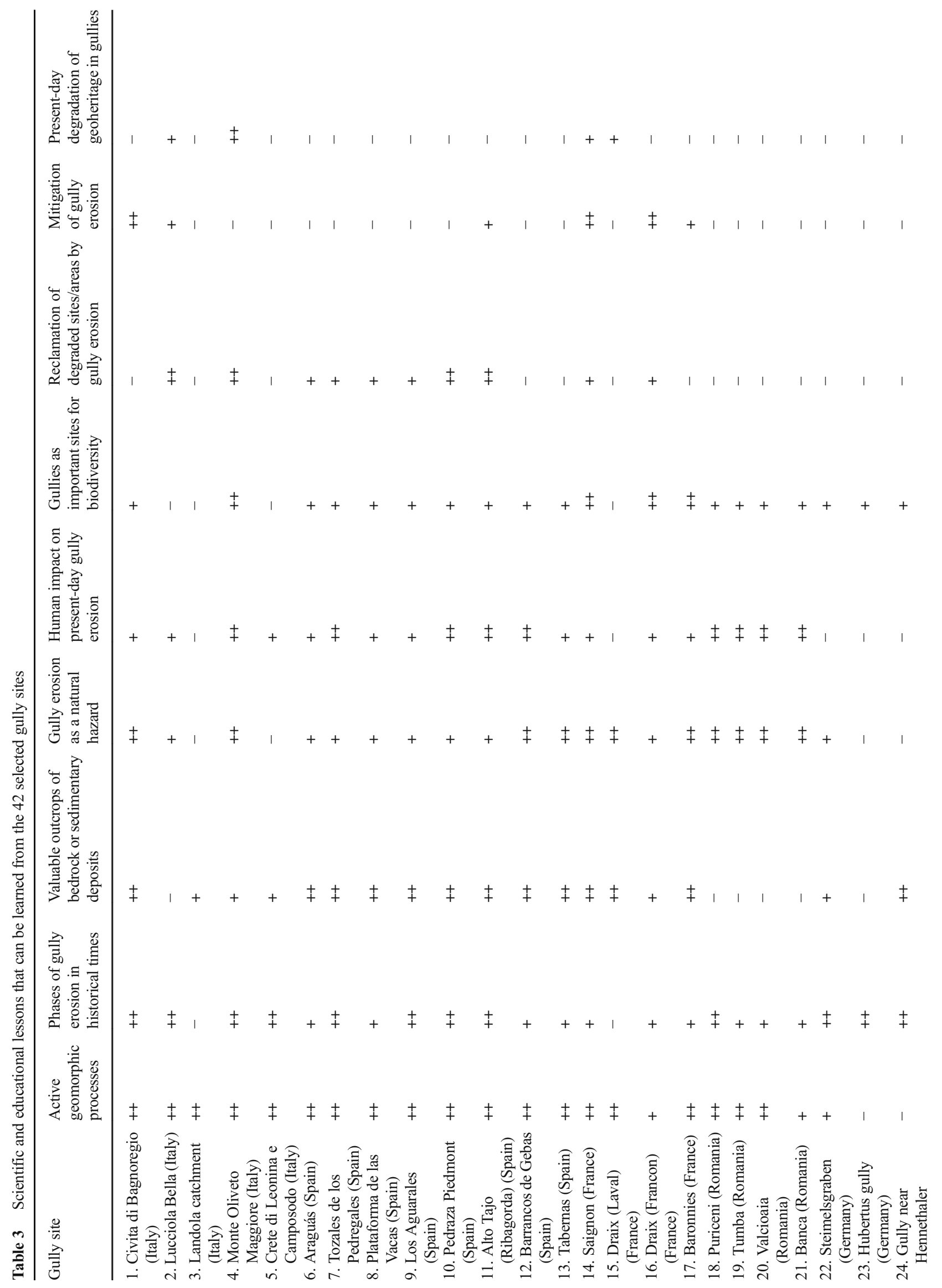




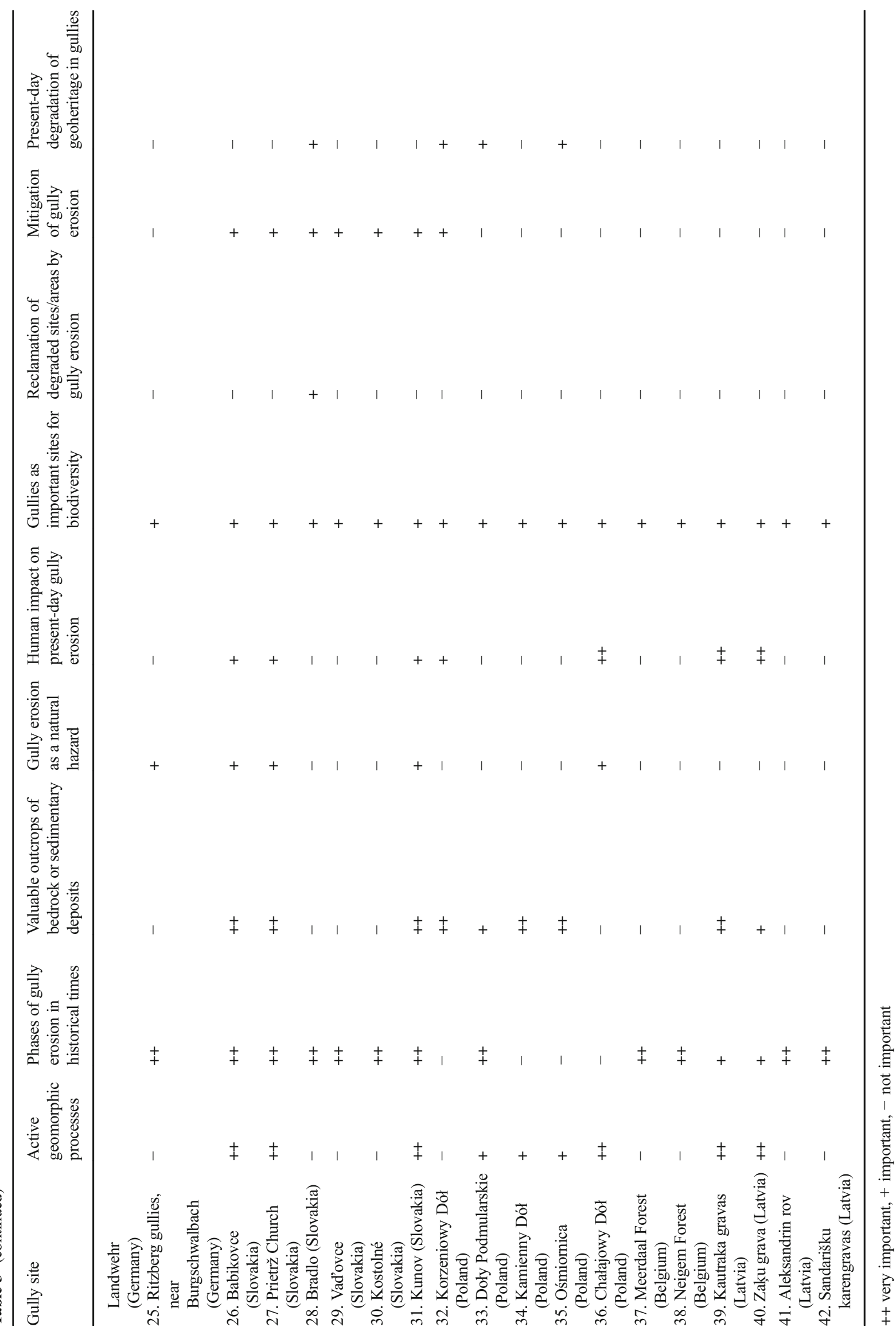


Table 4 Development of geotourism in studied countries

\begin{tabular}{|c|c|c|c|c|c|c|c|c|c|}
\hline & Italy & Spain & France & Romania & Germany & Slovakia & Poland & Belgium & Latvia \\
\hline National database of geosites & + & + & $-^{\mathrm{a}}$ & - & + & $+{ }^{b}$ & + & - & - \\
\hline Gullies as geosites & + & + & + & - & - & $+^{c}$ & + & - & - \\
\hline Gullies within geoparks & - & + & + & - & - & + & - & - & - \\
\hline Selected gullies as geosites & + & + & + & - & - & - & + & - & - \\
\hline Publications on geotourism within gully region & - & + & - & - & - & - & + & - & - \\
\hline
\end{tabular}

+ present, - not present

${ }^{a}$ The geological heritage inventory has been launched in 2007 by the French Ministry of Ecology and is still ongoing at the regional level

b The national database of "Important Geological Sites” was designed in 2012 by the State Geological Institute of Dionýz Štúr (cf. Významné geologické lokality 2015)

c Only a few gullies are included in the database, namely in thematic groups "Paleontology," "Archeology," and "Geomorphology." However, gullies are introduced as sites with a geological outcrop type and not as landforms

Also, in Slovakia, significant local transformation (deepening) of historical gullies by rare heavy rainfall event was documented (Stankovianksy 2003c; Stankoviansky and Ondrčka 2011).

A different situation occurs in Romania where currently severe gully erosion processes take place. Gullies within the Falciu Hills are excellent sites for observing status, type and intensity of geomorphological processes (Fig. 8c; Ionita et al. 2015).

\section{B. History of Landscape Changes}

The permanent gullies under forests testify that past land use changes also triggered severe soil erosion (Fig. 8d). These gullies were formed during the Bronze Age (Poland), Roman period (Belgium), Medieval times (Germany, Poland and Central Spain) or more recent periods (e.g. Slovakia, Romania and Italy). Such gullies indicate that significant soil erosion today is not always the consequence of modern agricultural techniques and that periods with relevant land degradation also occurred in the past. In Germany, the formation of gullies coincides with the history of charcoal production and iron works in their surroundings.

\section{Geological Window}

Badland landscapes in southern Europe (Spain, Italy and France) offer favourable conditions for observing the rock types in which they formed (Fig. 8a). In West and Central Europe, on the other hand, loose sediments deposited during the last glaciation are found. Here, large permanent gullies provide a geological window on fossil and recently formed soil horizons and subsurface sediment layers that are exposed in the gully walls where they can be easily observed. In some cases, the gully is sufficiently deep to outcrop the older bedrock in the gully bottom or walls. For example, such a situation occurs in a gully near Kazimierz Dolny (Poland) where a cross section with the Mesozoic/Cenozoic (K/T) boundary can be observed.

\section{Natural Hazard}

Gullying considerably affected the life of local inhabitants by decreasing the area of farmland, disrupting transport routes and depositing sediments on cropland, which resulted in extensive afforestation of gullied areas mostly during the last two centuries.

At Civita di Bagnoregio (Italy), the geomorphological hazard made the town to be known as the "dying town" (Fig. 8e), as the decline of the Civita town importance during the centuries testifies to several instability stages. The evolution of the gullied area is particularly evident along the access ridge to Civita, that since 1764 has undergone a lowering of about $40 \mathrm{~m}$. Land reclamation and monitoring programmes have been applied to prevent the spread and worsening of the instability affecting the Civita tufaceous cliffs overlying marine clays. In all the selected Italian sites, the gully hazard also affected farms and villages (such as the Chiusure Village and the Abbey of Monte Oliveto Maggiore), which are threatened by calanco head retreat. Gully erosion is the most important natural hazard in Falciu Hills (Romania). The gullies that developed here in modern times reduce the size of agricultural areas and are a source of considerable volumes of sediment that are transported from the hillslopes to the nearby rivers (Fig. 8c).

\section{E. Land Cover and Biodiversity}

Permanent gullies are usually found under forests in Central Europe where gully erosion rates decreased (e.g. Rodzik et al. 2009). The important role of human activities in gully development is confirmed by significant linkages between gullies and anthropogenic linear landscape elements (e.g. roads, parcel borders, earth banks) typical of historical land use patterns. Only a small number of gullies is purely controlled by hillslope topography, namely by thalwegs of dry valleys and dells or by landslides (e.g. Stankoviansky 2003a, b; Dotterweich et al. 2012). 


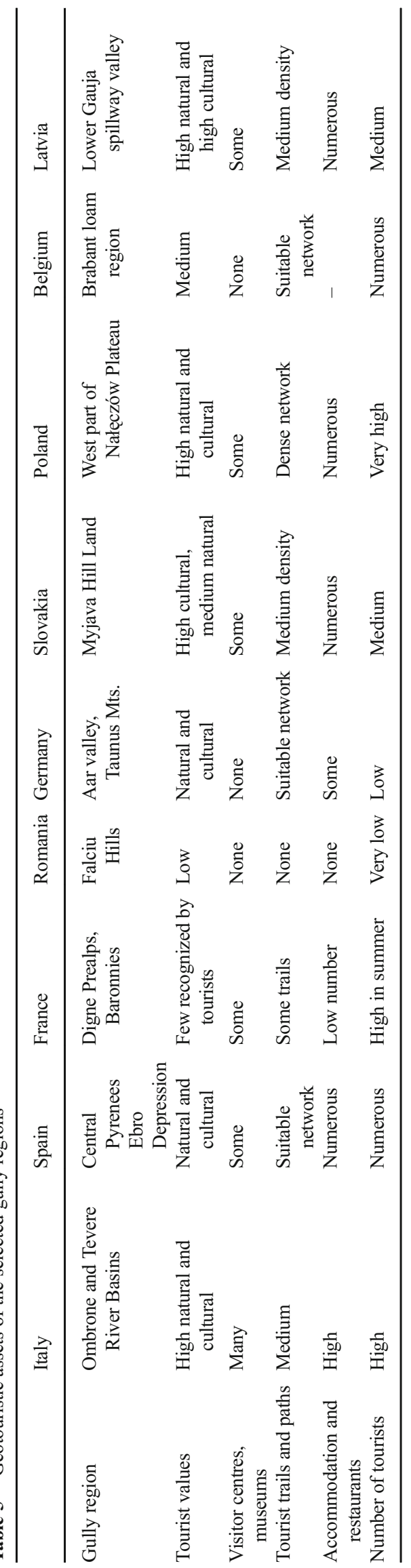

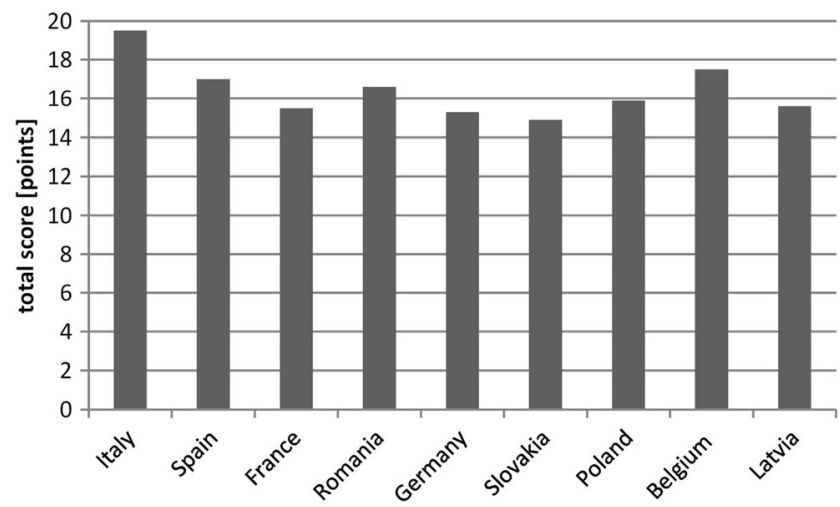

Fig. 5 Mean total country score for the geotouristic assessment of gullies as geomorphosites. For indicators and subindicators and related scores, see Table 2. Maximum possible score is 24

Gully erosion can also be a driver of land use change: in Central Europe, permanent gullies are often found in forest islands within cropland (Baran-Zgłobicka and Zgłobicki 2012). The large gully channels in old forests create a diverse landscape with likely more biodiversity due to the exposure of different lithologies and the microclimate they induce (cfr. road gullies or sunken lanes). In Italy, the obligations imposed by the changing of the sites into protected sites (partly because of endemic plant species, such as Artemisia caerulescens ssp. cretacea, and protected animal species, such as Canis lupus) favoured the ongoing encroachment of most of the gully sites by shrub and ruderal species. This is threatening the natural pioneering plant communities and the appearance of the gully sites, especially the biancana badlands (Maccherini et al. 2011).

\section{F. Mitigation, Reclamation and Sometimes Destruction of} Gullies

Mitigation and reclamation activities practically do not occur at the selected permanent gullies. In countries such as Belgium, Germany, Poland, Slovakia and Latvia, most

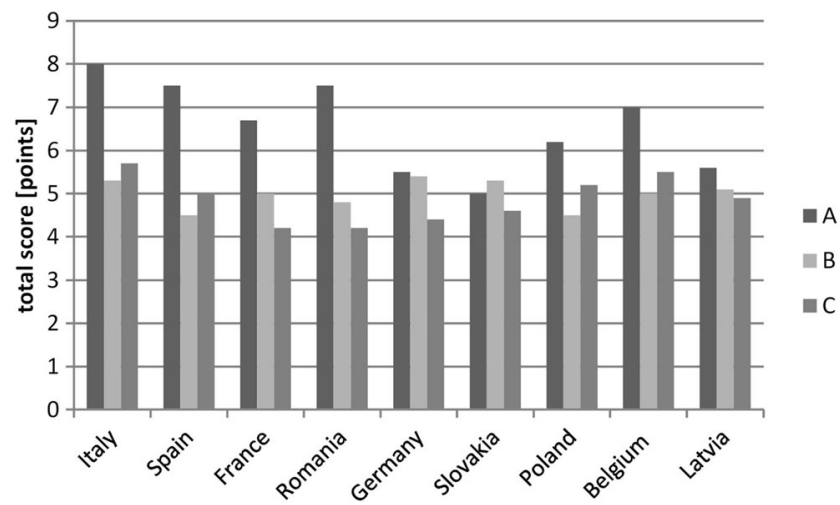

Fig. 6 Mean total country score for the three categories of geotouristic values of the selected gully sites: $a$ scientific and educational, $b$ functional and $c$ tourist. For indicators and subindicators and related scores, see Table 2 


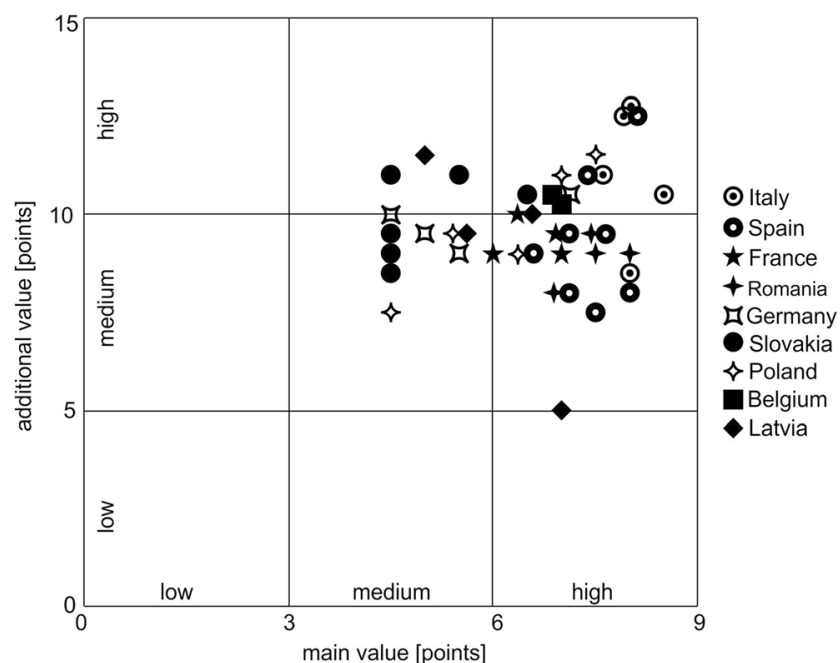

Fig. 7 Ranking of geomorphosites according to their main (scientific and educational) and additional (functional and touristic) values. For indicators and subindicators and related scores, see Table 2. Each data point refers to one of the 42 selected gully sites

permanent gullies are currently inactive; hence, there is no need to control them (e.g. Vanwalleghem et al. 2003; Stankoviansky 2003a, b; Dotterweich et al. 2012). The natural succession of forest communities is a process that reduces erosion rates. In southern Europe, on the other hand, badlands occur in sparsely vegetated areas which are not used for crop production; consequently, there is no direct need to control gully erosion.

In the French Alps, the selected gully sites offer bestpractice examples of how to control intense gully erosion in marls effectively using a combination of hard and soft engineering approaches, i.e. check dams, live vegetation barriers, and reforestation (Rey 2009). The gullied region of Central Spain also provides first-class worldwide examples of geomorphic reclamation solutions for mines developed on silica sand slopes, adjacent to gullies, where gullies are used as an analogous or reference for mining reclamation (therefore, only when this is a result of recent land degradation by humans) (Fig. 8f; Balaguer et al. 2014).

Some permanent gullies in Poland are subjected to degradation due to excessive tourist traffic (e.g. quad traffic). Also, in Spain, the lack of specific regulations concerning off-road vehicles (four-wheel-drive vehicles, quads, and trail motorbikes) might destroy some fragile geomorphological features like pinnacles, biocrusts and other micromorphological features characterizing some badland surfaces.
Fig. 8 Examples of most common scientific and educational lessons to be learned from gully sites. a Geological window allowing to observe subsurface rock type (Spain, photo: J.F. Martin Duque). b Active geomorphic processes: hydraulic erosion, piping, headcut erosion and mass wasting ( $\mathrm{E}$ Poland, photo: W. Zgłobicki). c Gully erosion as an environmental hazard (E Romania, photo: W. Zgłobicki). d Several phases of historical gully erosion and infilling reflecting past environmental changes (E Poland, photo: M. Dotterweich). e Civita di Bagnoregio (Central Italy, photo: A. Pica), known as the "dying town" due to the geomorphological hazard connected to the gully evolution. f Geomorphic reclamation based on the understanding of gully dynamics in Central Spain (Spain, photo: J.F. Martin Duque)
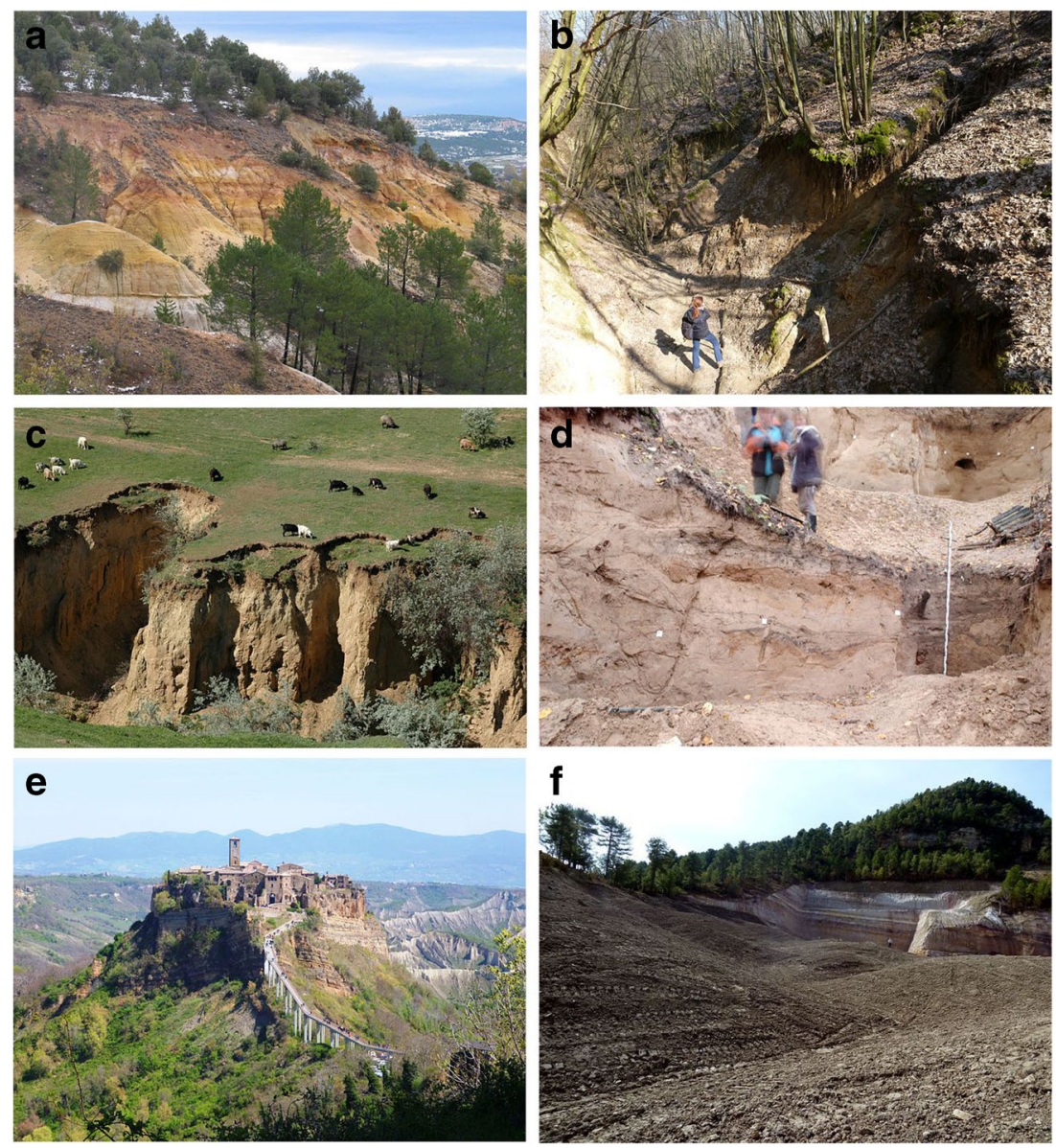


\section{Geotouristic Potential of Gullies}

The touristic and geotouristic potential of gullies is quite different in each country. In Spain, Italy and Poland, lists of geosites exist and gullies are located within the geoparks, in areas with high tourism value and well-developed infrastructure. On the other hand, gullies in Slovakia, Romania and Latvia are known almost exclusively by scientists. Also, the results of GAM showed that the scientific values of the gully sites are more important than touristic and functional values (Fig. 7). This indicates a need for more intense (but sustainable) development of tourism infrastructure and services at these sites. Comparing the results of the GAM model for gully sites in Europe with the GAM results presented by Vujičić et al. (2011), it should be noticed that permanent gullies were ranked higher than sites of Fruška Gora Mountain (Serbia). The study conducted by Vujičić et al. (2011) focusses on loess sections, quarries, and palaeontological sites, but the character of GAM makes it possible to compare results of assessments for different geosites. It should be noticed that none of the studied gully sites belong to the category of low values (main or additional), while in Serbia, two thirds of sites had low additional values and all of them only medium main values (Fig. 7).

In general, there was no correlation between scientific, functional, and tourist values. Educational and geoheritage promotion actions will thus depend on the level of familiarity with gullies. In places where gullies are tourist attractions, the main priority is to develop geotouristic products. In countries where gullies are unknown to tourists, their promotion as geomorphosites for geotourism has to be part of broader actions to develop tourism in the region and will require much greater investments.

In all countries, the promotion of gullies as geomorphosites must also be part of comprehensive geoheritage management because peculiarities of geology, hydrology and soil science can be showcased here alongside the geomorphological assets. Besides, some gullies also have biotic assets. It should be underlined that gullies have potential for the development of active, nature, sightseeing and cultural tourism.

\section{Gullies as Tourist and Geotouristic Attractions-Present Situation}

Most gully sites are spectacular in nature and therefore attract (geo)tourists. However, gullies look like a very familiar geomorphic feature in Romania and, thus, they usually do not represent an attraction for the common people. The calanco and biancana badland landscapes in central Italy define the identity of the territory. This aspect is highlighted by the UNESCO recognition of Val d'Orcia (Lucciola Bella and Landola catchment sites) in the World Heritage List. Likewise, Civita di Bagnoregio is recognized as a regional
Natural Monument. These gully sites are also of interest to soft tourism, related to enological and gastronomic tours, cyclo-tourism and religious tourism. At the moment, the cultural landscape and the ecological priorities of the sites are at the same time well-preserved and popularized. At present, the cultural landscape and the ecological priorities of the sites are well-preserved and advertised. The scientific interests of gullies and their progressive degradation or human-induced changes increase tourist appeal through frequent photographical expositions (e.g. in the Radicofani town, Val d'Orcia), thematic museums (e.g. the Geological and Landslides Museum in Civita di Bagnoregio) and interpretive boards along walking trails in the badlands.

The geomorphological component of the landscape is fundamental for the culture that arose in all the gully sites. The tourists appreciating the natural and the cultural landscape must understand the natural and human dynamics that generated them. The use of the term "geomorphosite" in the tourist infrastructures should be encouraged, and more collaboration between geotourism and classic tourism experts is needed. In this way, the advertising of gullies as geomorphosites could increase the awareness of equilibrium between human activities and natural processes in order to preserve the identity of the landscape. Furthermore, simulations of soil erosion and runoff could be organized during local tours in the badlands (e.g. by using a rainfall simulator and some beakers for collecting runoff and sediments) to illustrate soil aggregate stability upon wetting, differences in infiltration rates in recently weathered soft rocks and in soils at different stages of soil formation and soil erosion rates.

In Slovakia, until now, gullies play no role in tourism as they are under forests, and current attempts to popularize results of related scientific research are negligible. On the other hand, the tourist potential of selected gully sites is high as their formation and later development reflect relevant stages of regional to local land use history. Under these circumstances, the gully systems could help to reveal the pattern of former plots in the landscape where our ancestors operated. To turn this potential into reality is a great challenge for geomorphologists who so far have only produced scientific information. However, in order to attract geotourists to the gully sites, the interest of regional and local institutions is needed to establish educational paths equipped with interpretive boards.

At both the Meerdaal and Neigem forests (Central Belgium), there are information boards describing the origin of the gullies. Moreover, for the Meerdaal Forest, there is a booklet providing explanations about particular features in the forest, including the old gullies. Being so well-indicated and explained, gullies from these old forests constitute an additional attraction phenomenon for tourists.

The potential of Spanish badlands as geomorphosites is very high, due to a combination of various factors (Gouveia 
et al. 2016). Also, scientific publications and divulgation about these gullies are abundant. The main suggestion to promote the gully regions would be to link the geomorphic information with the historical and cultural tourism offered for the same region. In Spain, some gully sites are included in a UNESCO Geopark (e.g. Molina de Aragón-Alto Tajo, http://www.geoparquemolina.es/). In order to promote gullies as geomorphosites, one should include gully sites within the geopark initiatives.

Most gullies in the Aar valley of Germany are located in a peripheral and not densely settled region, without welldeveloped touristic infrastructure in the forests. Therefore, there is nearly no degradation, except by forestry activities, such as construction of forest roads and removal of tree trunks.

Gullies received little recognition as geomorphosites in France. In the main gully regions (i.e. Baronnies and Digne Prealps), little attention is given to gullies by tourism-based websites (tourist office, parks, and Google image websites). Gullied landscape is rarely shown by videos or images of tourism-based websites. In the Digne Prealps, gullies are mainly promoted as an adventure playground for mountain bikers or as scenic landscape for the observation of fossils (e.g. Ichthyosaure de La Robine in the Geopark). The limited recognition of gullies as geomorphosites has also been observed during enquiries among stakeholders and farmers of the Baronnies (Cohen et al. 2015).

A demonstration site for gully erosion control exists in the Saignon site (La Motte-du-Caire, Alpes-de-HauteProvence, France). Its topic is on "Forest restoration and bioengineering for erosion control on marly terrains". It is a trail, composed of one information board and ten stops with information provided in a notebook. Interpretive boards are present in the Draix site to explain the erosion and sediment-transport processes and the history of the geomorphic processes leading to gully formation as well. A demonstration site is planned for explaining the role of vegetation in reducing erosion and sedimentation and to present bioengineering techniques used for installing vegetation on degraded terrains. An information board has already been set up for explaining the researches devoted to these sites. A path crosses the site and could be used as a support for building the demonstration course.

In the loess region of the Lublin Upland (Poland), gullies are an important tourist attraction and are used to advertise the region (Fig. 9). Gullies are a unique landmark in some areas and appear on the cover of tourist guidebooks. Local tourist enterprise called "Land of loess gullies" exists here. A survey of visitors to these areas clearly shows that gullies cut in loess are the most recognizable and most highly rated of geomorphological heritage (Zgłobicki and Baran-Zgłobicka 2013). Another survey conducted among students of Maria CurieSkłodowska University in Lublin showed that more than $50 \%$ of them recently visited a loess gully (Zgłobicki et al. 2015b). Despite a high rating of the gullies' values, their geotourism potential has not been properly used. There is a lack of educational trails along gullies as well as suitable interpretive boards.

There are many ways to present information for geotourism (Newsome et al. 2012), namely, geosite panels, viewscape panels, geotrails, geotours, geological gardens, visitor centres and museums. It is also possible to use virtual tours, 3D visualizations (Aldighieri et al. 2016) and other modern techniques such as augmented reality and virtual media (Cayla 2014).

\section{Recommendations for Establishing Gullies as Geomorphosites}

There are several actions required to be taken to promote gullies as geo(morpho)sites. The most important ones are presented below.

The promotion of gullies as geomorphosites must be part of the development of geotourism in the region, for example, by including them in initiatives associated with the existing or planned geoparks. It is advisable to emphasize the value of gullies for other forms of tourism (active, nature, cultural).

Educational trails with interpretation boards should be the basic tourism product. Modern techniques and media should also be used to promote gullies as tourist and geotouristic attractions. It is especially important to develop professional and user-friendly webpages - Internet is now a basic source of information about geoheritage.

It is important to develop staff and tour-guide training programmes, especially in less spectacular sites (Newsome et al. 2012). The gully erosion research community has an important role to play in the promotion of gullies as interesting geosites. It is necessary not only to identify the scientific and educational values of particular gully sites but also to deploy appropriate efforts to develop geotourism products.

It is indispensable to learn from the views of tourists on gullies as tourist and geotourist attractions so that the developed products meet their expectations. One should also study the attitude of local people to geotourism in gully regions and underline the economic and social benefits for them as a result of their development.

\section{Conclusions}

Based on a detailed analysis of gully regions and gully sites in Europe, the following conclusions regarding gullies as geomorphosites can be drawn.

Gullies do have a significant educational value as they may contribute to a better understanding of the lithology (via outcrops in gully walls) and hence the geology of a region, active geomorphic processes (erosion and sediment deposition) and phases of historical gully erosion reflecting significant 
Fig. 9 Tourists exploring an old gully (left) and a road gully (right) in the Lublin region (Poland) (photo R. KołodyńskaGawrysiak)
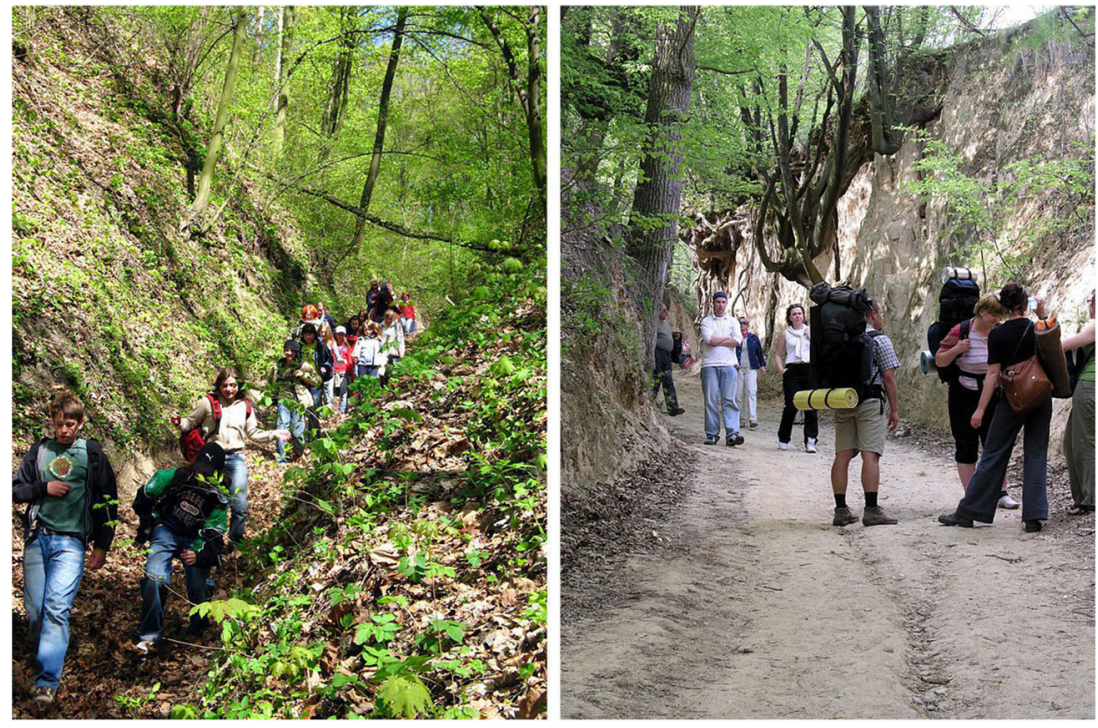

environmental changes (human-environment interactions, climate). The scientific aspects that can be highlighted at particular gully sites varied, but they always consist of at least three to four topics.

The geotouristic potential of gullies varies significantly within this subcontinent: it is the highest in Italy and Spain and the lowest in Romania and Latvia. This results primarily from the level of touristic development in the studied gully regions and sites. Therefore, promotion of gullies as geomorphosites varies as well.

Currently, the geotouristic exploitation of gullies in Europe is quite limited. Except for isolated sites in southern Europe, Belgium, Poland and Germany, gullies are not known to (geo)tourists. Their popularity does not always correspond to their geoheritage value. Geomorphologists dealing with gullies and gully erosion must get more involved in developing geotourism in the regions with permanent gullies.

\section{Compliance with Ethical Standards}

Funding The research in Slovakia was supported by the Slovak Research and Development Agency under the contract no. APVV0625-11. Estela Nadal-Romero was the recipient of a "Ramón y Cajal" postdoctoral contract (Spanish Ministry of Economy and Competitiveness). Geomorphic reclamation initiatives on gullies degraded by mining, in Central Spain, are supported by the Ecological Restoration Network 502 REMEDINAL-3 of the Madrid Community (S2013/MAE-2719).

Open Access This article is distributed under the terms of the Creative Commons Attribution 4.0 International License (http:// creativecommons.org/licenses/by/4.0/), which permits unrestricted use, distribution, and reproduction in any medium, provided you give appropriate credit to the original author(s) and the source, provide a link to the Creative Commons license, and indicate if changes were made.

\section{References}

Aldighieri B, Testa B, Bertini A (2016) 3D exploration of the San Lucano Valley: virtual geo-routes for everyone who would like to understand the landscape of the Dolomites. Geoheritage 8(1):77-90. doi:10.1007/s12371-015-0164-x

Alexander D (1980) I calanchi: accelerated erosion in Italy. Geography 65(2):95-100

Aucelli PPC, Conforti M, Della Seta M, Del Monte M, D'uva L, Rosskopf CM, Vergari F (2014) Multi-temporal digital photogrammetric analysis for quantitative assessment of soil erosion rates in the Landola catchment of the Upper Orcia Valley (Tuscany, Italy). Land Degrad Dev 27(4):1075-1092. doi:10.1002/ldr.2324

Balaguer L, Escudero A, Martín-Duque JF, Mola I, Aronson J (2014) The historical reference in restoration ecology. Biol Conserv 176:12-20. doi:10.1016/j.biocon.2014.05.007

Ballais JL (1996) L'âge du modelé de roubines dans les Préalpes du Sud. Géomorphologie relief processus. Environ Forensic 1996(4):61-68

Ballesteros Cánovas JA, Stoffel M, Martín-Duque JF, Corona C, Lucía A, Bodoque JM, Montgomery DR (2017) Gully evolution and geomorphic adjustments of badlands to reforestation. Sci Rep 7:45027. doi: 10.1038/srep45027

Baran-Zgłobicka B, Zgłobicki W (2012) Mosaic landscapes of SE Poland: should we preserve them? Agrofor Syst 85:351-365. doi: 10.1007/s10457-011-9436-X

Bollati I, Reynard E, Palmieri EL, Pelfini M (2016) Runoff impact on active geomorphosites in unconsolidated substrate. A comparison between landforms in glacial and marine clay sediments: two case studies from the Swiss Alps and the Italian Apennines. Geoheritage 8(1):61-75. doi:10.1007/s12371-015-0161-0

Bork HR, Bork H, Dalschow C, Faust B, Piorr HP, Schatz T (1998) Landschaftsentwicklung in Mitteleuropa: Wirkungen des Menschen auf Landschaften. Klett-Perthes, Gotha 328 pp

Braga JC, Baena J, Calaforra JM, Coves JV, Dabrio C, Feixas C, Fernández JM, Gómez JA, Goy JL, Harvey AM, Martin JM, Martin A, Mather AE, Stokes M, Villalobos M, Zazo C (2003) Geology of the arid zone of Almería, an educational field guide. State Water Company for the Southern Basin (ACUSUR) and Environmental Agency of the Andalucia Province Council, 163 pp

Bučko Š, Mazúrová V (1958) Výmol’ová erózia na Slovensku. In: Zachar D (ed) Vodná erózia na Slovensku. Slovak Academy of Sciences, Bratislava, pp 68-101 
Calvo-Cases A, Harvey AM, Alexander RW, Cantón Y, Lázaro R, SoléBenet A, Puigdefábregas J (2014) Badlands in the Tabernas Basin, Betic Chain. In: F. Gutiérrez and M. Gutiérrez (eds), Landscapes and landforms of Spain, Springer Science+Business Media, Dordrecht, pp 197-212

Calzolari C, Ungaro F (1998) Geomorphic feature of a badlands (biancane) area (Central Italy): characterisation, distribution and spatial analysis. Catena 31(4):237-256. doi:10.1016/S03418162(97)00046-5

Castillo C, Gomez JA (2016) A century of gully erosion research: urgency, complexity and study approaches. Earth-Sci Rev 160:300-319. doi:10.1016/j.earscirev.2016.07.009

Cayla N (2014) An overview of new technologies applied to the management of geoheritage. Geoheritage 6(2):91-102. doi:10.1007/ s12371-014-0113-0

Cerdà A (1998) Post-fire dynamics of erosional processes under Mediterranean climatic conditions. Z Geomorphol 42(3):373-398

Cohen M, Rey F (2005) Dynamiques végétales et érosion hydrique sur les marnes dans les Alpes françaises du Sud. Géomorphol: Relief, Proc Environ, $n^{\circ} 1,31-44$. doi: 10.4000/geomorphologie. 223

Cohen M, Rey F, Vila J, Ubeda X (2015) Landscapes and erosion in the Mediterranean mountains. A comparison between France, Spain and Italy, Chapter 3. In: Luginbuhl Y, Howard P, Terrasson D (eds) Landscape and sustainable development. The French Perspective, Farnham, pp 37-46

Constante A, Peña-Monné JL, Muñoz A (2010) Alluvial geoarchaeology of an ephemeral stream: implications for Holocene landscape change in the central part of the Ebro Depression, Northeast Spain. Geoarchaeology 25(4):475-496. doi:10.1002/gea.20314

Coratza P, De Waele J (2012) Geomorphosites and natural hazards: teaching the importance of geomorphology in society. Geoheritage 4(3): 195-203. doi:10.1007/s12371-012-0058-0

Coratza P, Bruschi VM, Piacentini D, Saliba D, Soldati M (2011) Recognition and assessment of geomorphosites in Malta at the IlMajjistral Nature and History Park. Geoheritage 3(3):175-185. doi: 10.1007/s12371-011-0034-0

De Ploey J (1989) Soil erosion map of western Europe. Catena Verlag, Cremlingen-Destedt

Del Monte M, Fredi P, Pica A, Vergari F (2013) Geosites within Rome city center (Italy): a mixture of cultural and geomorphological heritage. Geogr Fis Din Quat 36(2):241-257. doi:10.4461/GFDQ. 2013.36.20

Del Monte M, Della Seta M, Melelli L, Vergari F, Ciccacci S (2014) Intensità dell'erosione nel bacino idrografico del Rio Torbido (Bagnoregio, VT). Atti del Convegno Dialogo intorno al Paesaggio (Perugia, 19-22 Febbraio 2013). Cult Territori Linguaggi 4(I):107-116

Desir G, Marín C (2007) Factors controlling the erosion rates in a semiarid zone (Bardenas Reales, NE Spain). Catena 71(1):31-40. doi:10. 1016/j.catena.2006.10.004

Dotterweich M (2008) The history of soil erosion and fluvial deposits in small catchments of Central Europe: deciphering the long-term interaction between human and the environment-a review. Geomorphology 101(1-2):192-208. doi:10.1016/j.geomorph. 2008.05.023

Dotterweich M, Rodzik J, Zgłobicki W, Schmitt A, Schmidtchen G, Bork H-R (2012) High resolution gully erosion and sedimentation processes, and land use changes since the Bronze Age and future trajectories in the Kazimierz Dolny area (Nałęczów Plateau, SEPoland). Catena 95:50-62. doi:10.1016/j.catena.2012.03.001

Dunbar PK (2007) Increasing public awareness of natural hazards via the Internet. Nat Hazards 42(3):529-536. doi:10.1007/s11069-0069072-3

Erhartic B (2010) Geomorphosite assessment. Acta Geogr Slov 50(2): 295-319. doi:10.3986/AGS50206
Garavaglia V, Pelfini M (2011) Glacial geomorphosites and related landforms: a proposal for a dendrogeomorphological approach and educational trails. Geoheritage 3(1):15-25. doi:10.1007/s12371-0100027-4

García Ruiz JM, López Bermúdez F (2009) La erosión del suelo en España. Sociedad Española de Geomorfología, Zaragoza 441 pp

García-Ruiz JM (2010) The effects of land uses on soil erosion in Spain: a review. Catena 81(1):1-11. doi:10.1016/j.catena.2010.01.001

García-Ruiz JM, Nadal-Romero E, Lana-Renault N, Beguería S (2013) Erosion in Mediterranean landscapes: changes and future challenges. Geomorphology 198:20-36. doi:10.1016/j.geomorph.2013. 05.023

Gawrysiak L, Harasimiuk M (2012) Zróżnicowanie przestrzenne gęstości wąwozów na Wyżynie Lubelskiej i Roztoczu. Ann UMCS B 67:27-43

Ginesu S, Secchi F (2009) Geomorphosites in granitic environments: an example from northern Gallura (north-eastern Sardinia, Italy). Boll Soc Geol Ital 128(3):723-729. doi:10.3301/IJG.2009.128.3.723

Giusti C (2010) Introduction to the thematic issue: from geosites to geomorphosites: how to decode the landscape? Geodynamic processes, surficial features and landforms, past and present environments. Geomorphol-Rel Proc Environ 16(2):123-130. doi:10.4000/ geomorphologie.7947

Giusti C (2012) Les sites d'intérêt géomorphologique: un patrimoine invisible? Géocarrefour 87(3-4):151-156

Giusti C, Calvet M (2010) The inventory of French geomorphosites and the problem of nested scales and landscape complexity. Geomorphol-Rel Proc Environ 16(2):223-244. doi:10.4000/ geomorphologie.7947

Giusti C, Joyeux O, Toquet E (2013) Géotope, géofacies et géosystème: une grille de lecture des paysages géomorphologiques? Le Cas De La Réserve Naturelle Nationale Des Aiguilles Rouges, ChamonixMont-Blanc Haute-Savoie, France. Conference: Gestion des géosites dans les espaces protégés - managing geosites in protected areas, at Chambéry (Savoie) - Chamonix-Mont-Blanc (HauteSavoie), 7-10 September 2011, Volume: Collection EDYTEM, ${ }^{\circ}$ 15, 17-32. doi: 10.13140/2.1.2327.6485

Goudie AS (2004) Encyclopedia of geomorphology. Routledge, London

Gouveia CM, Páscoa P, Russo A, Trigo RM (2016) Land degradation trend assessment over Iberia during 1982-2012. Cuadernos de Investigación Geográfica 42(1):89-112. doi:10.18172/cig.2945

Gregori L, Melelli L, Rapicetta S, Taramelli A (2005) The main geomorphosites in Umbria. Il Quat Ital J Quater Sci 18(1):137-143

Hose TA (2013) 3G's for modern geotourism. Geoheritage 4(1):7-24. doi:10.1007/s12371-011-0052-y

Ielenicz M (2009) Geotope, geosite, geomorphosite. The annals of Valahia University of Targoviste. Geogr Ser 9(2009):7-22

Ionita I (2006) Gully development in the Moldavian Plateau of Romania. Catena 68(2-3):133-140. doi:10.1016/j.catena.2006.04.008

Ionita I, Niacsu L, Petrovici G, Blebea-Apostu AM (2015) Gully development in eastern Romania: a case study from Falciu Hills. Nat Hazards 79(1):113-138. doi:10.1007/s11069-015-1732-8

Józefaciuk A, Józefaciuk C (1996) Erozja wąwozowa i metody zagospodarowania wąwozów. PIOŚ, Warszawa

Kale VS (2014) Geomorphosites and geoheritage sites in India. In: Kale VS (ed) Landscapes and landforms of India. Springer, World Geomorphological Landscapes, pp 247-267

Kubaliková L (2013) Geomorphosite assessment for geotourism purposes. Czech J Tour 2:80-104. doi:10.2478/cjot-2013-0005

Kubalíková L, Kirchner K (2016) Geosite and geomorphosite assessment as a tool for geoconservation and geotourism purposes: a case study from Vizovická vrchovina Highland (eastern part of the Czech Republic). Geoheritage 8(1):5-14. doi:10.1007/s12371015-0143-2

Kuhlman T, Reinhard S, Gaaff A (2010) Estimating the costs and benefits of soil conservation in Europe. Land Use Policy 27(1):22-32. doi: 10.1016/j.landusepol.2008.08.002 
Lecompte M, Lhenaff R, Marre A (1998) Huit ans de mesures du ravinement des marnes dans les Baronnies méridionales (Préalpes françaises du sud). Géomorphologie Relief Processus. Environ Forensic 1998(4):351-374

Lucía A, Laronne JB, Martín Duque JF (2011) Geodynamic processes on sandy slope gullies in central Spain. Field observations, methods and measurements in a singular system. Geodin Acta 24(2):61-79

Maccherini S, Marignani M, Gioria M, Renzi M, Rocchini D, Santi E, Torri D, Tundo J, Honnay O (2011) Determinants of plant community composition of remnant biancane badlands: a hierarchical approach to quantify species-environment relationships. Appl Veg Sci 14(3):378-387. doi:10.1111/j.1654-109X.2011.01131.x

Maher E, Harvey AM (2008) Fluvial system response to tectonically induced base level change during the late-Quaternary: the Río Alias southeast Spain. Geomorphology 100(1-2):180-192. doi:10. 1016/j.geomorph.2007.04.038

Martín-Moreno C, Fidalgo Hijano C, Martín Duque JF, González Martín JA, Zapico Alonso I, Laronne JB (2014) The Ribagorda sand gully (eastcentral Spain): sediment yield and human-induced origin. Geomorphology 224:122-138. doi:10.1016/j.geomorph.2014.07.013

Mathys N, Brochot S, Meunier M, Richard D (2003) Erosion quantification in the small marly experimental catchments of Draix (Alpes de Haute Provence, France). Calibration of the ETC rainfall-runofferosion model. Catena 50(2-4):527-548. doi:10.1016/S03418162(02)00122-4

Mathys N, Klotz S, Esteves M, Descroix L, Lapetite JM (2005) Runoff and erosion in the Black Marls of the French Alps: observations and measurements at the plot scale. Catena 63(2-3):261-281. doi:10. 1016/j.catena.2005.06.010

Midriak R (1966) Erózia spustnutých pôd Perísk. In: Vedecké práce Výskumného ústavu lesného hospodárstva vo Zvolene, 7; 17-42

Nadal-Romero E, Regüés D (2010) Geomorphological dynamics of subhumid mountain badland areas - weathering, hydrological and suspended sediment transport processes: a case study in the Araguás catchment (Central Pyrenees) and implications for altered hydroclimatic regimes. Prog Phys Geogr 324(2):123-150. doi:10. 1177/0309133309356624

Nadal-Romero E, Regüés D, Martí-Bono C, Serrano-Muela P (2007) Badland dynamics in the Central Pyrenees: temporal and spatial patterns of weathering processes. Earth Surf Process Landf 32(6): 888-907. doi:10.1002/esp. 1458

Nadal-Romero E, Latron J, Lana-Renault N, Serrano-Muela P, MartíBono C, Regüés D (2008) Temporal variability in hydrological responses within a small catchment with badland areas, central Pyrenees. Hydrol Sci J 53(3):629-639. doi:10.1623/hysj.53.3.629

Nadal-Romero E, Martínez-Murillo JF, Vanmaercke M, Poesen J (2011) Scale-dependency of sediment yield from badland areas in Mediterranean environments. Prog Phys Geogr 35(3):297-332

Neboit R (2010) L'Homme et l'érosion. Presses Universitaires BlaisePascal, Clermont-Ferrand 359 pp

Neches IM (2013) From geomorphosite evaluation to geotourism interpretation. Case study: the Sphinx of Romanian's Southern Carpathians. GeoJ Tour Geosites 12(2):145-162

Neugirg F, Stark M, Kaiser A, Vlacilova M, Della Seta M, Vergari F, Schmidt J, Becht M, Haas F (2016) Erosion processes in calanchi in the Upper Orcia Valley, Southern Tuscany, Italy based on multitemporal high-resolution terrestrial LiDAR and UAV surveys. Geomorphology 269:8-22. doi:10.1016/j.geomorph.2016.06.027

Newsome D, Dowling R, You-Fai L (2012) The nature and management of geotourism: a case study of two established iconic geotourism destinations. Tour Manag Perspect 2-3:19-27. doi:10.1016/j.tmp. 2011.12.009

Panizza M (2001) Geomorphosites: concepts, methods and example of geomorphological survey. Chin Sci Bull 46(1):4-6. doi:10.1007/ BF03187227
Papčo P (2014) What can be interesting for geotourism development in an agricultural landscape? Soil erosion. In: GEOTOUR \& IRSE 2014: conference proceedings (16-18 October 2014, Miskolc, Hungary). Technical University of Košice, Košice, pp 35-43

Pereira P, Pereira D (2010) Methodological guidelines for geomorphosite assessment. Géomorphologie-Relief, Processus, Environnement 16(2):215-222. doi:10.4000/geomorphologie.7942

Poesen J, Hooke JM (1997) Erosion, flooding and channel management in Mediterranean environments of southern Europe. Prog Phys Geogr 21(2):157-199. doi:10.1177/030913339702100201

Poesen J, Nachtergaele J, Verstraeten G, Valentin C (2003) Gully erosion and environmental change: importance and research needs. Catena 50(2-4):91-133. doi:10.1016/S0341-8162(02)00143-1

Radoane M, Ichim I, Radoane N (1995) Gully distribution and development in Moldavia, Romania. Catena 24(2):127-146. doi:10.1016/ 0341-8162(95)00023-L

Rey F (2009) A strategy for fine sediment retention with bioengineering works in eroded marly catchments in a mountainous Mediterranean climate (Southern Alps, France). Land Degrad Dev 20(2):210-216. doi:10.1002/ldr.905

Reynard E (2004) Geosite. In: A.S. Goudie (ed.), Encyclopedia of Geomorphology, vol. 1. Routledge: 440

Reynard E (2005) Geomorphological sites, public policies and property rights. Conceptualization and examples from Switzerland. Il Quaternario 18(1):323-332

Reynard E (2008) Scientific research and tourist promotion of geomorphological heritage. Geografia Fisisica e Dinamica Quaternaria 31: 225-230

Reynard E, Coratza P (2007) Geomorphosites and geodiversity: a new domain of research. Geogr Helv 62:138-139

Reynard E, Fontana G, Kozlik L, Scapozza C (2007) A method for assessing scientific and additional values of geomorphosites. Geogr Helv 62(3):148-158

Reynard E, Coratza P, Giusti C (2011) Geomorphosites and geotourism. Geoheritage 3(3):129-130. doi:10.1007/s12371-011-0041-1

Reynard E, Coratza P, Hobléa F (2016a) Current research on geomorphosites. Geoheritage 8(1):1-3. doi:10.1007/s12371-0160174-3

Reynard E, Perret A, Bussard J, Grangier L, Martin S (2016b) Integrated approach for the inventory and management of geomorphological heritage at the regional scale. Geoheritage 8(1):43-60. doi:10.1007/ s12371-015-0153-0

Rodzik J, Furtak T, Zgłobicki W (2009) The impact of snowmelt and heavy rainfall runoff on erosion rates in a gully system, Lublin Upland, Poland. Earth Surf Process Landf 34(14):1938-1950. doi: 10.1002/esp. 1882

Sancho C, Peña JL, Muñoz A, Benito G, McDonald E, Rhodes EJ, Longares LA (2008) Holocene alluvial morphosedimentary record and environmental changes in the Bardenas Reales Natural Park (NE Spain). Catena 73(3):225-238. doi:10.1016/j.catena.2007.09.011

Schotmans J, Poesen J, Vanmaercke M (2015) Hoe zijn ravijnen in oude bossen ontstaan? Studiegeval Neigembos. Jaarboek De Aardrijkskune 2015. In press

Solarska A, Jary Z (2010) Geoheritage and geotourism potential of the Strzelin Hills (Sudetic Foreland, SW Poland). Geogr Pannonica 14(4):118-125

Soms J (2011) Development and morphology of gullies in the River Daugava Valley, South-Eastern Latvia. Landf Anal 17:179-188

Stankoviansky M (2003a) Historical evolution of permanent gullies in the Myjava Hill Land, Slovakia. Catena 51(3-4):223-239. doi:10.1016/ S0341-8162(02)00167-4

Stankoviansky M (2003b) Geomorfologická odozva environmentálnych zmien na území Myjavskej pahorkatiny. Comenius University, Bratislava $152 \mathrm{pp}$ 
Stankoviansky M (2003c) Gully evolution in the Myjava Hill Land in the second half of the last millennium in the context of the CentralEuropean area. Geogr Pol 76(2):89-107

Stankoviansky M, Ondrčka J (2011) Current and historical gully erosion and accompanying muddy floods in Slovakia. Landf Anal 17:199 204

Stolz C (2008) Historisches Grabenreißen im Wassereinzugsgebiet der Aar zwischen Wiesbaden und Limburg. Geologische Abh. Hessen 117, Wiesbaden $138 \mathrm{pp}$

Stolz C, Grunert J (2006) Historic land-use and gully formation, a case study from the Taunus mountains/southern Rhenish Slate Massif. Zeitschrift für Geomorphologie, N.F. Supplement 142:175-194

Thomas M (2012) A geomorphological approach to geodiversity - its applications to geoconservation and geotourism. Quaest Geogr 31(1):81-89

Tooth S (2009) Invisible geomorphology? Earth Surf Proc Landf 34:752754. doi:10.1002/esp. 1724

Torri D, Colica A, Rockwell D (1994) Preliminary study of the erosion mechanisms in a biancana badland (Tuscany, Italy). Catena 23(3-4): 281-294. doi:10.1016/0341-8162(94)90073-6

Torri D, Calzolari MC, Rodolfi G (2000) Badlands in changing environments: an introduction. Catena 40(2):119-125. doi:10.1016/S03418162(00)00119-3

Torri D, Santi E, Marignani M, Rossi M, Borselli L, Maccherini S (2013) The recurring cycles of biancana badlands: erosion, vegetation and human impact. Catena 106:22-30. doi:10.1016/j.catena.2012.07.001

Valentin C, Poesen J, Li Y (2005) Gully erosion: impacts, factors and control. Catena 63(2-3):132-153. doi:10.1016/j.catena.2005.06.001

Vallauri D, Aronson J, Barbero M (2002) An analysis of forest restoration 120 years after reforestation on badlands in the Southwestern Alps. Restor Ecol 10(1):16-26. doi:10.1046/j.1526-100X.2002.10102.x

Vanmaercke M, Poesen J, Van Mele B, Demuzere M, Bruynseels A, Golosov V, Bezerra J, Bolysov S, Dvinskih A, Frankl A, Fuseina Y, Guerra A, Haregeweyn N, Ionita I, Imwangana F, Moeyersons J, Moshe I, Nazari Samani A, Niacsu L, Nyssen J, Otsuki Y, Radoane M, Rysin I, Ryzhov Y, Yermolaev O (2016) How fast do gully headcuts retreat? Earth Sci Rev 154:336-355. doi:10.1016/j. earscirev.2016.01.009

Vanwalleghem T, Van Den Eeckhaut M, Poesen J, Deckers J, Nachtergaele J, Van Oost K Slenters C (2003) Characteristics and controlling factors of old gullies under forest in a temperate humid climate: a case study from the Meerdaal Forest (Central Belgium). Geomorphology 56(1-2), 15-29. doi:10.1016/S0169-555X(03) 00043-6

Vanwalleghem T, Poesen J, Van Den Eeckhaut M, Nachtergaele J, Deckers J (2005) Reconstructing rainfall and land use conditions leading to the development of old gullies. The Holocene 15(3): 378-386. doi:10.1191/0959683605hl807rp

Vanwalleghem T, Bork HR, Poesen J, Dotterweich M, Schmidtchen G, Deckers J, Scheers S, Martens M (2006) Prehistoric and Roman gullying in the European loess belt: a case study from central Belgium. The Holocene 16(3):393-401. doi:10.1191/ 0959683606hl935rp
Vergari F (2015) Assessing soil erosion hazard in a key badland area of Central Italy. Nat Hazards 79(1):71-95. doi:10.1007/s11069-0151976-3

Vergari F, Della Seta M, Del Monte M, Fredi P, Lupia Palmieri E (2013) Long- and short-term evolution of several Mediterranean denudation hot spots: the role of rainfall variations and human impact. Geomorphology 183:14-27. doi:10.1016/j.geomorph.2012.08.002

Vittorini S (1977) Osservazioni sull'origine e sul ruolo di due forme di erosione nelle argille: calanchi e biancane. Boll Soc Geogr It 10(6): $25-54$

Vujičić MD, Vasiljević DA, Marković SB, Hose TA, Lukić T, Hadžić O, Janićević S (2011) Preliminary geosite assessment model (GAM) and its application on Fruska Gora Mountain, potential geotourism destination of Serbia. Acta Geogra Slov 51(2):361-377. doi:10. 3986/AGS51303

Významné geologické lokality (2015) [online database] Project Leader: Pavel Liščák. [Cited 2015-09-16]. Available on http://mapserver. geology.sk/g vgl/?jazyk=SK

Warowna J, Migoń P, Kołodyńska-Gawrysiak R, Kiebała A, Zgłobicki W (2013) Geomorphosites of Poland - the role played by the Central Register of Geosites. Landf Anal 22:117-124

Warowna J, Zgłobicki W, Gajek G, Telecka M, Kołodyńska-Gawrysiak R, Zieliński P (2014) Geomorphosite assessment in the proposed Geopark Vistula River Gap (E Poland). Quaest Geogr 33(3):173180. doi:10.2478/quageo-2014-0040

Warowna J, Zgłobicki W, Kołodyńska-Gawrysiak R, Gajek G, Gawrysiak L, Telecka M (2016) Geotourist values of loess geoheritage within the planned Geopark Małopolska Vistula River Gap, E Poland. Quat Int 399:46-57. doi:10.1016/j.quaint.2015.06.064

Wiederkehr E, Dufour S, Piegay H (2010) Location and semi-automatic characterisation of potential fluvial geomorphosites. Examples of applications from geomatic tools in the Drome River basin (France). Geomorphol-Rel Proc Environ 16(2):175-188. doi:10. 4000/geomorphologie.7912

Yamakoshi T, Mathys N, Klotz S (2009) Time-lapse video observation of erosion processes on the Black Marls badlands in the Southern Alps, France. Earth Surf Process Landf 34(2):314-318. doi:10.1002/esp. 1701

Yitbarek TW, Belliethathan S, Stringer LC (2012) The onsite cost of gully erosion and cost-benefit of gully rehabilitation: a case study in Ethiopia. Land Degrad Dev 23(2):157-166. doi:10.1002/1dr.1065

Zgłobicki W, Baran-Zgłobicka B (2011) Gullies as an indicator of human impact on loess landscape (case study: north western part of Lublin Upland, Poland). Zeitschrift für Geomorphologie 55. SI 1:119-137

Zgłobicki W, Baran-Zgłobicka B (2013) Geomorphological heritage as a tourist attraction. A case study in Lubelskie Province. SE Poland Geoheritage 5(2):137-149. doi:10.1007/s12371-013-0076-6

Zgłobicki W, Baran-Zgłobicka B, Gawrysiak L, Telecka M (2015a) The impact of permanent gullies on present-day land use and agriculture in loess areas (E. Poland). Catena 126:28-36. doi:10.1016/j.catena. 2014.10.022

Zgłobicki W, Gawrysiak L, Kołodyńska-Gawrysiak R (2015b) Gully erosion as a natural hazard: the educational role of geotourism. Nat Hazards 79(1):159-181. doi:10.1007/s11069-014-1505-9 